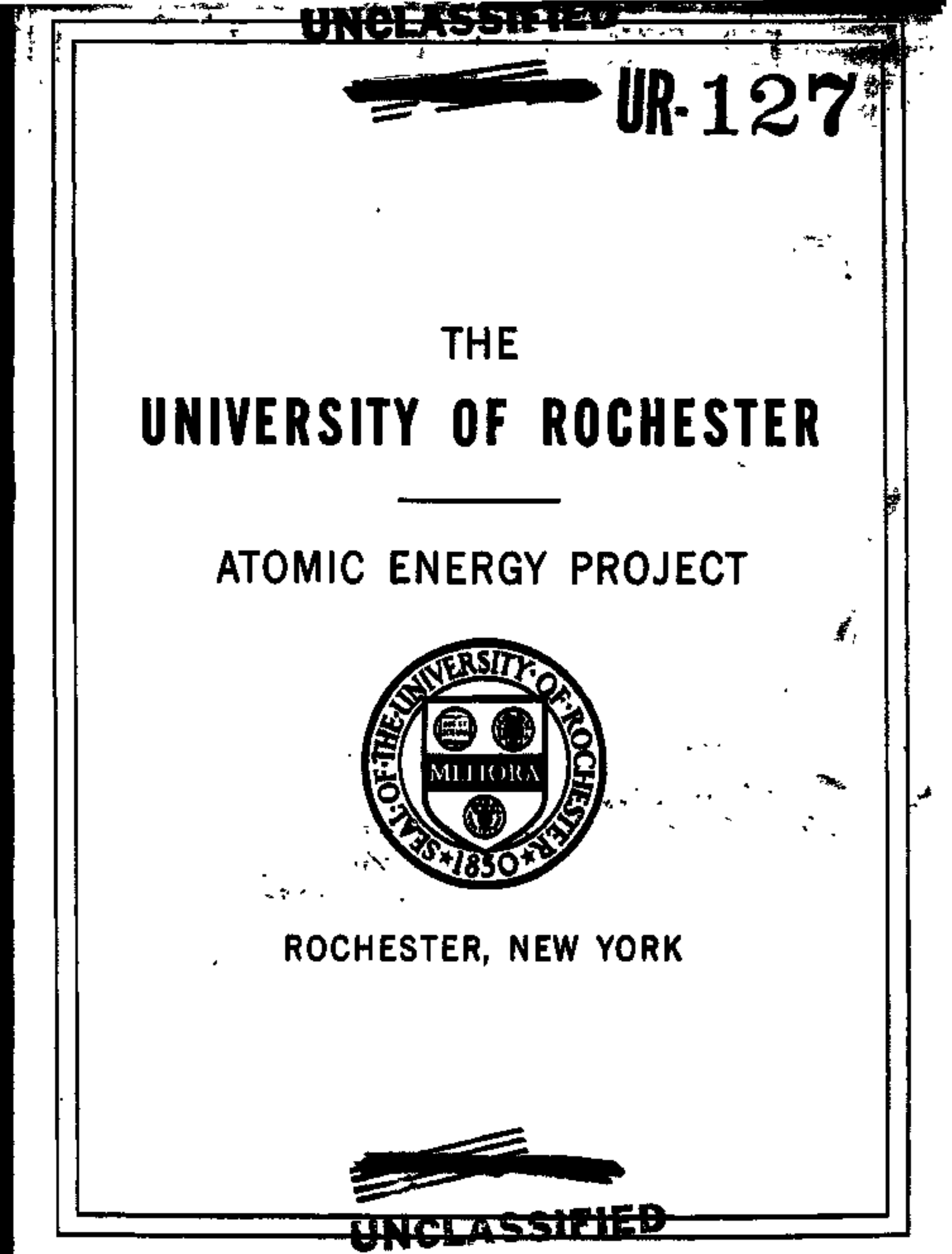




\section{DFol Dix:}

Portions of this docmoment may be illegible is electronic immete produets. Ineses are produced from the best avaliable origtinal docoment. 

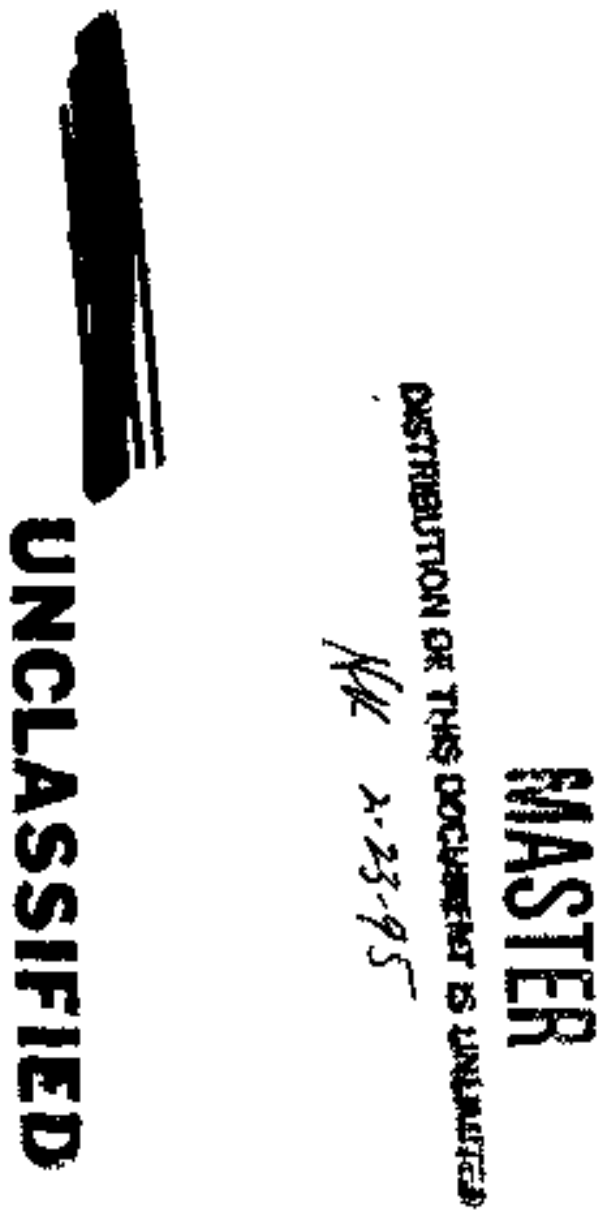

This report wes prepared al an ateount of wark sponsored by an agency af the Unted Stules

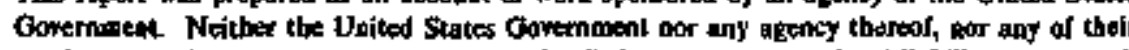

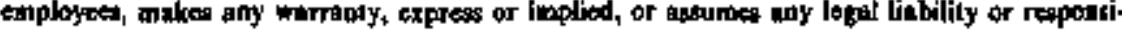

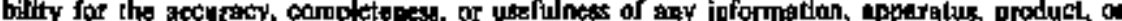

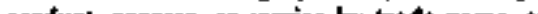

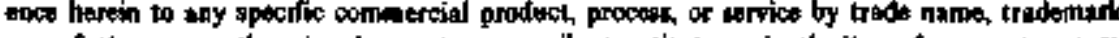
menofactore, or othorwise does nol necessarily constitute or impty its endorsenent, recom. mendelion of favociat by the Unaled Sialos Gowernment of any agency thetsor. The views and apinions of authors experested herein to non nectusarily slote or reflect loose of the Ueited Stales Governateot of any agency thereof.
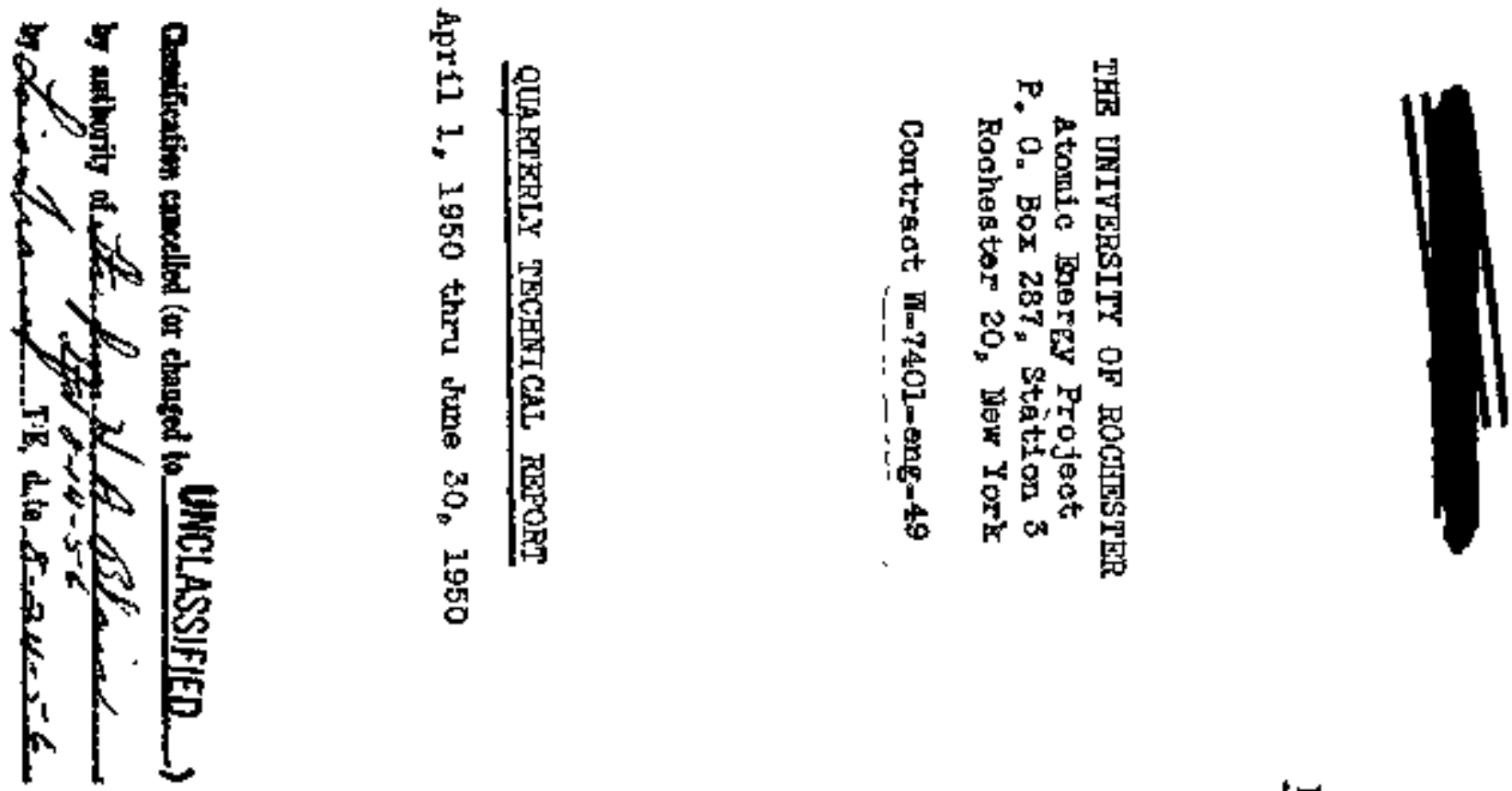
Standard Distribution

Argonne Ifational Laboratory

Armed Forces Special Waspons Projoct

Atoutc BerE Commission, Trashington

Battelle Yemorial Institute

Arookharen National Laboratory

Bureau of Mediotine and Surgery

Carbide and Carbon Chenioals Corporation (K-25 Flant)

Carbide and Carbon Chemicsla Corporation (Y-12 Flant)

Chicego Operations Office

Columbia University (Dumning)

Columbia Juiversity (Patlla)

General Ilectrio Compeny, Richlend

Hanford Operations Office

Idaho Operations office

Iowe state College

Zellex corporettion

Fnolla Atomis Power Laboratory

tos alamos

Hallinokrodt Chemical Horks

Wassachusetts Institute of Teohnology (Kaufriann)

Mound Laboratory

Hational Advisory Combittee for Aeronaltics

Naval Hedical Research Institute

Maval Radiologiogl Defenes Laboratory

MEPA Project

Hew Erunswiek Laboratory

New York Operetions office

North American Aviation, Ino.

Oak the Hational Laboratory

Patent Branch, Fiashington

Fublio Health Service

Sylvania Electric Products, Inc。

Technical Information Branoh, OHE

JGLA Lsdioal Resesroh Laborstory (Parrem)

Thitersity of Califomie Rediation Leboratory

University of Chioago Toxiefty Laboratory

thiversity of Washington

Festern Reserve University (Rrtedelis)

Neatinghouse Eleotrio Corporation
No. Copses

8

1

3

1

4

1

2

4

1

1

1

6

1

2

1.

1

2

3

1

1

3

1

1

1

I

1

3

1

B

1

1

1

15

1

6

I

1

4

1

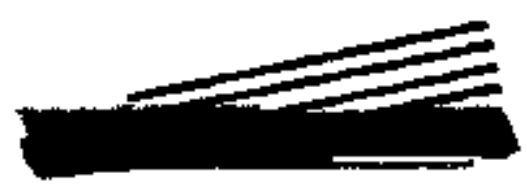


Health and Biology

DISTRTBUTIOE OF REPORT UR-127 (cont.)

Internal Diatribution (Bochester)

Ho. Copies

Technical Report Control

Liforery

Dr. A. F, Dowdy

Dr. H. A. Blair

Dr. T. F. Bale

Dr. J. B. Hursh

Dr. Lo L. Hiller

Jr. G. W. Cesarett

Dr. K. Sel on

Har. Hicheel Thatson

Dr. J. F. Stannard

Dr. I. T, Bteadinan

Dr. H, Co Hodge

Dr. H. B. Stokinger

Dr. F, A. Sinith

Dr. W. $F$. Velumar

Dr. E. Hzynard

Dr. J. K. Bcott

Dr. A. Rothstein

Dr. J. H. Howland

Mr. Ho Hermagen

Mr. R. Bayres

Dr. H. L. Ingram

Dr。 G. B. Hider

Dr. K. B. Hason

Dr. H. L. Bratford

Dr. E. D. Kingaley

1

1

I

1

Dr。 W. B. Mason

Dra $S_{0} L$ orrump

Dr. F. Rrrth

Lr. $H_{0}$ Thipple

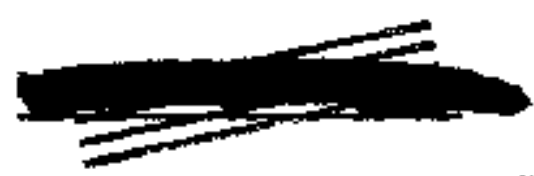


Page Ho.

I. IHTRODUCTION ........................

II. HXPLANGTION OF PROGRAM ARD PRORLEM CODES ............

III. FROGRAM AME PROBLAM CODES $\ldots \ldots \ldots \ldots$

IV. ORRAEIZATION - JPIVEESITY OF BOCHESTER ATOMIC ENERGY PROJECT. * 12

7. RESEARCH AND SEEVICE ACTIVITIES.................

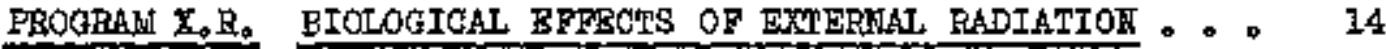

Problen $X_{0} R_{0} 1 \ldots \ldots \ldots 14$

Probler $Z_{4} R_{0} 2 \ldots \ldots \ldots 23$

Problem $x_{0} R_{0} 3 \ldots \ldots 28$

Problem X, R, $4 \ldots \ldots \ldots 8$

RROGRAK U。 URANIUN ................... 41

Problem $\mathrm{\sigma}_{0} 4$..................... 41

PROGRALF F. FLUTORIDE ................... . . 51

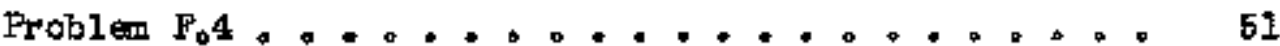

PROGRAM ZI Z ZIRCONIUM .................. 61

Froblen $\mathrm{Zt} \mathrm{3} \ldots \ldots \ldots$

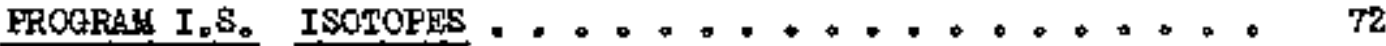

Froblem $I_{a} S_{0} 3 \ldots \ldots \ldots 72$

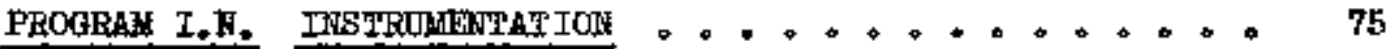

Problerr $I_{0} H_{0}{ }_{1} \ldots \ldots \ldots \ldots \ldots$

Problem $I_{8} \mathrm{H}_{\phi} 2 \ldots \ldots . \ldots \ldots$ 
5.

Page Ho。 $_{0}$

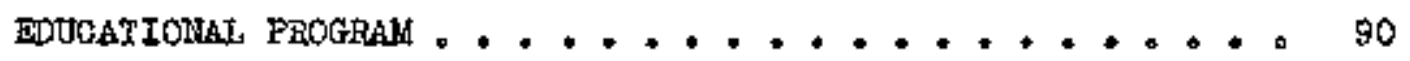

TI. TEEENICAL REPORTS ISSUJED FOR DISTRIBUTION $\ldots \ldots \ldots$........ 84 
6.

\section{IHTRODUCTION}

The solmtstic work presented kereln bas been coded at the program ard problem levels according to the schems given on Pages 7 and 8 . In the report all oontributions to a gtren problem heve been sssembled together without rogard to the adeinfstrative organization except thet the nunber of the section which did the work is prefixed tn each gase. By using this number, it oan be found on Page 12 what sdmintstrattre offloer oen be approached for information about particular work.

It should be noted that the Quarterly Technioal Reports of the Thiversity of Rochester Atcinio Bnergy Project do not atteript to describe progress in all of the researoh progrsms but only th those in which 8 ams signifloant resul ts hare been abieved but whioh aro not suffloiently complete to be witten up as a flnal report. 


\section{EXPLANATION OF PROGRAI AND PROBLMA CODES}

The sciertific work at The University of Roohester Atomio Energy Froject has been coded at the progrem and problesn levels. The prograns, in general, indloate broad fields of Investigetive or servioe aotivities while the problems indicate difialons of these fielde. Although no consistent method of division in problems was posibla, an attempt was nade to achieve a netural divisson in the sense that each probler would encompess a subject normally written up and generally congidered as a unit. The program or chemicel toxicity of ureniur, for excuple, has been broken down into problems according to the dvistons conmonly emplayed by toxloologists.

The problem codes are not related directly to the administrative organization of the Project, consequently, the smallest sdministrative unit, the seotion, may work on more than ons of the coded problems conversely, more than one eection may work or the same coded problem, The administratfve organization will be ignored in making this quarterly report of our regearch and service activities, all tuaterial being assembled according to the program and problean codes. The oontribution of each goction to a Quartorly Techioal Report will be prefixed by the gectlon number, however, to perait reference to the administrative organization if necessary.

It has not been possible to code the problems sufficientily broedly to avoid all overolapping. In oases in which vartous perts of a given investigation might be coded aifferently, the whole work was coded aocording to 1 ts principal. oubject mattex as Iong as the minor subjects wers reletively umimportant. Otherwign, the work was divided mder appropriate codes。 
I. $x_{0} R_{*}$ BIOLOGIOAL BFFECTS OF EXTERNAL RADIATION (X-RAYS AND Y RAYS)

$I_{0} R_{9} 1$ Tolerence studies (dose levels, surrival time, gross and histo-pathology)

X.R.2 Hechantsm of Effects (phystologioal and biochemicel)

$x_{0} H_{\infty} 3$ Therapy (measures agafnst radiation effects)

$\mathrm{x}_{0} \mathrm{R}_{\mathrm{a}} 4$ Hemptology

$X_{\alpha} R_{a} 5$ Genetics (híatogenetics)

$X_{0} R_{0} 6$ Fnbryology

X.R.7 Bacteriology and Imanuology

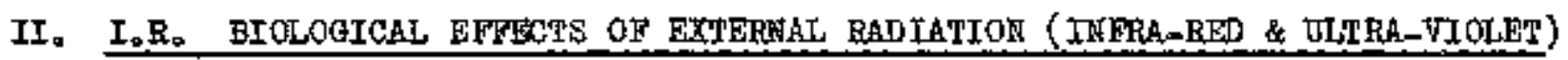

$I_{0} R_{a} 1$ Flash Burna

III. R,H, BIOLOGICAL BFFECTS OF RADIOACTIVE MATBRIALS (CONTACT, IVGESTIOH, EIC

$R_{0} H_{\phi} l$ Polonium

R.M.2 Radon

$\mathrm{R}_{0} \mathrm{H}_{8} \mathrm{3}$ Thorom

$\mathrm{R}_{0} \mathrm{M}_{0} 4$ Miscellaneous Projeot Letalg

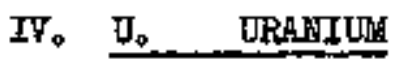

U. I Physioal and Chemionl Properties

U.2 Toxlo fiffects (description of acute and chronio toxicity)

D.3 Toxic timits (regpiratory; oral; skin; eyro; parenteral)

W.4 Fate (dsatribution and exeretion)

D.5 Jechanison of Toxic Fffects

U.6 Wethods of Detection of Poisoning, Prophylaxis, Treatment and Protection 
V. Be, BERYLIJux

Be.l Physiosl and Chempol Properties

Be.2 Toxie Effeots (desaription of gotute and chronic toxiof ty)

Be.3 Toxic Limits (respiratorys orkl; skin; eyes parenteras)

Be,4 Fate (distribution and exoretion)

Be.5 Wechanism of Toxio Effeots

Be.6 Methods of Deteotion of Poisoning. Prophylaxis, Treatment and Protection

\section{Tho THORTul}

Th.l Prystcal and Chemical Properties

'Th.2 Toxio Effects (description of aoute and obronfo toxiofty)

Th,3 Toxit Limits (respiratory; oral; skin; eye; parenteral)

Th.4 Fate (diatribution and excretion)

Th, 5 Lechanisen of Toxlc Effeots

Th,6 Methods of Deteotion of Poisoning, Prophylaxil, Treatruent and Proteotion

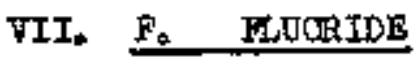

Fol Physteal and Chemiogl Proporties

$F_{0} 2$ Toxio Effeota (description of acute and chronic toxioity)

F.3 Toxio Linfts (reapiratory; oral; skin; eye; parenteral)

Fo4 Fate (distribution and exoretion)

F.5 Meohanism of Toxis Effect

F.6 Methods of Detection of Poisoning, Prophylaxis, Treatment and Prateotion. 
VIII. 2

2r.1 Fhysical and Chemical Propertios

Zx.2 Toxic Effects (desoription of aoute and chronio toxiofty)

Zro3 Toxio Lfoltz (rosplratory; oral; skin; oye; paranteral)

$2 r .4$ Fate (distribution and excretion)

$z_{\text {r.5 }}$ leohanism of Toxic Befect

Zro6 Methods of Detection of Polsoning. Prophylaris, Treatment and Frotection

EX S. SO SPECIAL MATERIATS

Sollol Phystoal and Chemical Propertfes

$\mathrm{S}_{0} \mathrm{H}_{0} 2$ Taxic Effeots (description of soute and chronto toxicty)

S.Mo3 Toxsc Limits (respiratory: oral; skin; ege; parenteral)

S.M.4 Fate (dfstribution and exoretion)

G.Ha5 Yechanism of Toxje Efreot

$\dot{S}_{0} H_{0} 6$ fothods of Detaction of Poisoning, Prophylaxis, Treataent and Protootion

X. $I_{0} S_{0}$ ISOTOPEB

Io $S_{0} 1$ Tracer Chenistry

$I_{0} S_{0} 2$ Radioautography

I. S.3 Therapy

$X I$, 0,S。 OTTSIDE SERVICE

XII. P.H. FROJECT ERALTH 
11.

XIII. H.P. HEAITH FHYSIGS

H.P.I Fesearch and Deqelopment

$\mathrm{H}_{0} \mathrm{P}_{*} 2$ Serviog

XIV. C.S. SPECIAI GIINICAI SBRVICE

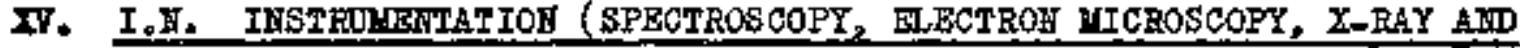

GUCLEAR RADIATION DETECTORS, X-RAY DIFFRACTION, EHECTROIICS)

I.H.i Research and Development

I.Na2 Service

I.M.3 Instrumentation for Outside Orgenfations 


\section{ORCANIZATION}

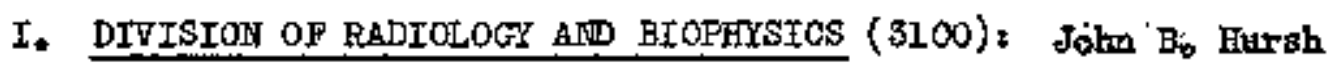

\begin{tabular}{|c|c|c|}
\hline Seotion code & Section & Administrative Hend \\
\hline $31 \pm 0$ & Instrunentation & John Bo Hursh \\
\hline 3120 & Traoer Chomistry & Leon $L$ 。 Millar \\
\hline 3130 & Rediation Tolerence & John B. Fursh \\
\hline 3136 & Radfation Physiology & Jolm B. Hursh \\
\hline 3140 & Radiation Chemlistry & Kurt Sal conon \\
\hline 3150 & Spectroasopy & Iutille T. Steadroon \\
\hline 3160 & Radiation Mechanjos & Wicheal Wetson \\
\hline 3170 & Radiation Toxicology & J. Newell Stamard \\
\hline 3171 & Radionutography & $J_{0}$ Newell Stannara \\
\hline
\end{tabular}

II. DIVISION OF PEARAACOLOGY ABD TOXICOLOGY (3200)8 Harold $c_{0}$ Hadge

\begin{tabular}{|c|c|c|}
\hline Seation code & Seotion & Adainistrative Head \\
\hline 3210 & Indastrial Hygiens & Herbert $\mathrm{E}_{\theta}$ Stokinger \\
\hline 3220 & Btochenistry & Wilifiam $F_{*}$ Heiman \\
\hline 3230 & Ingestion Toxicity & Ellizatt baynard \\
\hline 3250 & Pathology & Jemes $\mathrm{K}_{0}$ Soott \\
\hline 3260 & Physiology & Aser Botheteln \\
\hline
\end{tabular}

III DIVIS ION OF MEDICAL SARVICES (3300) $\times$ Joe Wo Howland, $\mathrm{H}_{\circ} \mathrm{D}_{\circ}$

\begin{tabular}{cll} 
Section code & \multicolumn{1}{c}{ Section } & Administratire Head \\
3310 & Inotopes and Service & Jo Russoll Hayes \\
3320 & Medioal Physics & Herbert Mermagen
\end{tabular}


Section Code

$\$ 3350$

3340

3350

3351

3370

3380

3390
Section

Froject Wedical Service

clinical Chomiatry

Therepy

Bequatology

Mouse Genetios

Bnoryology

Photographio Service
Administrative Head

pharylou Ingrem

H. Burkett 战son

Fragk Wo Furth

Harylou Ingram

Eiloen Otis

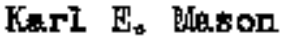
Jeneg Go 而lson

Robert L. Hey

IV. RESEARCH SBFVICE

Section Code

3480

3490

Educational

Statiotics

V. SPECLIAL RESEARCH PROGRAM

Section Code

Section

2602

Flash Barn

2604

Zircaritu
Administrative Head

J. MowelI Stamard

S. Lae Grump

Adminisatrative Head

Harry Do Kingsley

Eerbert E。 Stoklnger 


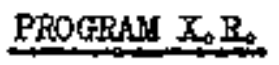
BIOLOGICAL EFFECTS OF EXTEHML RADIATION (X-RATS AID $\gamma$ RAYS)

Froblem Codet X.R.I (Tolerance Studies)

Seotion Cods: 3130

Anthors. G. W. Casarett

Effects of X-raye on Spermatogenesis in Dogs.

Beckeround. From prefious experiments Initiated under the direction of Dr. Andrew $\mathrm{H}_{\mathrm{D}}$ Dowdy and Dr. Robert Bache, it is known that ahronis z-radiation (total-body) at dosage levels of $1.0 \mathrm{r}$ or grater per day produce o condition of aspermia in doga within one yearo A dose of 0.5 r per day produces 2 lowered spern ooroentration in dog semen tith canplete asperaie in same oaves Sperm cownte were made on dogs exposed to $O_{\mathrm{a}} I$ I per day of x-irradiation ard a small, but statistioaldy signifloant deprassion in sperin ooncentration oocurred.

These studies mere not of primary consideration in the experiments intolved and wore of necessity inccmplate and not extensive。

We have initiated and are carrying out a chronio study on dogs in en endegror to disoorer the lowest dosage lerel at which significant ohanges in sperin and sperm conoentration on be inducect. Young male beagles are betng used, with litters represented in each dosage group insofar as is possible. Fhen daily irradietion is begun it is plemnod to continus such oxposures orer the reproductive lifetine of these enimals or until algaificant resulta have been obtained at the lowegt radiation I erels.

The dosage levels whioh will be used for this extensive study of dog semen and spermatosoa are: 


\section{DNCLASST FER}

$$
\begin{array}{r}
\text { Controls - } 20 \text { dogs } \\
0.05 \mathrm{r} / \mathrm{day}-20 \mathrm{dog} s \\
0.10 \mathrm{r} / \mathrm{day}-10 \mathrm{dogs} \\
0.50 \mathrm{r} / \mathrm{day}-10 \mathrm{dogs} \\
\text { Totel }-60 \mathrm{dog} a
\end{array}
$$

The dogs used for this atudy are being oarefully assembled. Littere of 3 or 4 thoroughtsed beegle puppies are belug astigned to experimental groups In such a fashton as to permit batisfactory stetistical handing of the resulte. If the restiti of radiation atudies on spermatozen of doge ean be transferred to mon, the simiflcance in setting a permanent permits sible luman Exposure lepel of radiation is apparent.

However, in terms of sterility and fertility of the male, gpermatozo concentration alone, exoept when drastioally reduced, has little meaning. That is, fertility may be greatly reduoed without great ohange in speral oonoestration. Therefore, other seainal and aperutozoal faotors influenceng mele fertility are important subject, for study,

\section{Purpose. To determines}

1. The minimal chronic dose of x-radiation whioh will depress the consentration of apermatoron in dog semen or effect other chonger in spermatozon,

2. The effect of chronic $x$-radiation the proposed dosage Iovels on motility, viability, and norphology of aperinatozon;

3. The offect of chronic $x$-radiation at these dogage 1 orels on the

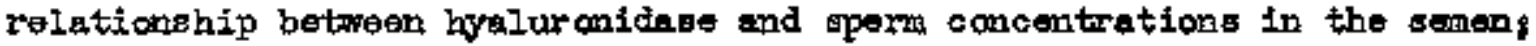

4. The ability of the semen and aparm to recover at varlous intervals of time from changes whtch mey be produced at certain dosage levels. Hethods. Stnoe even the oldest dogs have not yet reached a point of ERICLASSI FIDID 
stability and unifomity with regard to sexual excitability oate end regularity of collection of semen, volume of ejaculate, and production of spermatozon, radiation has not begun.

Gollections of semen wre firgt attempted at the age of 8 months and at weakly intervals thereafter. The oldest $\operatorname{dog}^{3}$ at the present tian are only 11 months old. Volumes of ejaculate are often very smell and do not perntit acourate or complete andysis of senen.

For these reasons the begirming of $x$-radistion is not yet indicated, and no quentitative results wil be presented hereo However, extensite work has been done on the methods and teohniques and on the elimination of as auch of the personal and experiaental error as possible.

Techifques and masurenent methods have been dereloped for determining an index of potential fertility in the male Some of the garatical methods of E. J. Farris have been modified for our use.

Any chenge in a property of a spermatozoon which prevents the spermatozoon from reaching an ovul is in effect as important in fertizity and sterility as the existence or nonexistence of a spermetozoon, $i_{0} e_{0}$, faotors preventing the function of apermatozoa are at least as impartant in a deteraination of fertility as a determination of spen conoentration alome.

Spern conoentration, except when drastiealiy lorered, means very little in terms of fertifity without a knowledge of the ather factors discuksed beloro Coilection of Sermen Semples, Collection of semen samples from the dog is accosplished by nasturbation, $i_{0} e_{0}$, the production of organm and enfiasion by maniptulation of the genitals by hand, Just prior to mastiribation, the male dog is placed with a female dog tutil he becomes exoited enough to mount the femsle. A stell table for collection of semsa during the faounting provedure 
is to be bufit shortly. The efaculate is oollected in a graduted tube and the rolume and time recorded.

If the bitch is in heat, the sexual oxcitement and active participation of the male dog are greater, and the ejaculate more complete end caplous. Fengle dogs come into heat anly trioe a year, usuldy to the spring and fall. Samples are more difficult to obtain without the aid of a bitoh in heat, ond those obtained thus were oftan jucomplete. In order to overcone this probien, hornone treatment wh uasd in an attempt to bring about at leat the oxoitatory phases of the heat period in a female dog out of sedson.

It was found that the intramuscular injection of '30 mgo of stilberstrol In saltne, $10 \mathrm{mg}$. In each of three injections spaced two days epart, in a female dog which had had its heat pertod 5 or 6 weeks before, was followed, after a period of saveral days by all of the external tigns of an intensive "heat" period, with tumesoence of the external genitala, secretion of flusds, and grest sexual excitament on the pert of the female and also on the males exposed to har. It is not known as yot whather orulation hes sctually taken place. This dow has now been in heat for 8 or 9 days so far, other female dogs whioh have ackpleted their spring heat cycle are being given the same treatuent, and repetition and aubstantiation of this reaxit is boling saited.

At the present time there is no way of showing by direot megns that masturbation or this form of "interruptus coitus" provides a semple idantical with that supplied in copulation, since there is no objective evidenoe oncernIng the oontent of the ejaculation during norpal coitus it segals roasonable to assume, howerer, that the ejeculato provided by coitus interruptus compares favorably with that resulting from uninterrupted cottis determined that for the bunan, masturbation gives approximately the sane results UEUIASSIFIND 
as coitus interruptus. The consistent and successfol results obtained by Farris' bethods, which hinge upon the use of insturbation to get senen sanples, tends to support the vien that for all practical purposes the specinen resulting Prom masturbation is representative of the semen depostted in intercourse. In the present dog experiment, now that it seems posstble to obtain

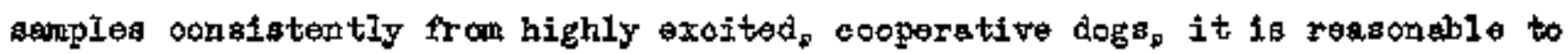
ansure that the serples so obtained will be axficientiy similar to those produog in nomal ooftus to allow, upon analysis, a good means for pradiotion of the degree of fertility in the dogs.

The persod of time betweon emsions in a sexually mature dog for the sperantozoe count to reach sts maximum level has not yet been marked out satzisfactorily, not only because the dogs do not yet shor indisputable oridenoe of sexual maturity on the basis of spermatoroa production, but because until racently the lack of excitatory means made consistent collection of good samples difficult. Fith the aid of the bitch in heat the number of dog 8 manpled aucoesefully, as well as the volume and sperm population of the specimens, has Inoreased。 Sampling atteenpts had been made at weikly intervels, but tro-meol intervals seem indioated at the present time. Increased rolumes of e jaculate will nor tend to allow application of all malytical procedures to sach amplo. Motility. The "absolute notility" or the number of moving spermatozon In the total ejaculate is of prime importanos stnoe only moving spermatozon are likely to effeot fertilization of ovat

Inoke's flusd in used to dilute the semen in order to keap the spermatomon alive, aotive, sond nomal, thereby permitting a differential count of both the eative and inactive apermatosoa.

A knom difution of well-pixed segren ia made by the addition of Locke DTCLASSI FIES 


\section{DNCLASSIFIED}

fiufd. The spermatozos are oounted in five groups of 18 sind squares in the red flold of an heemocytometer, routinely the four oorner groups and the oenter group. The spermatozoa in both chambers are coumted and areraged.

The courting chember is saled with vaseline after loading, tn order to prevent evaporation from the sample。 The spermatozon retain their motility for mang hours in this Bealed preparation. The counting, horever, is done at an barly Interval after colleotion and dilution of gemen.

A systematic oount of active and innotive celis is made in order to obtain the per pent of mots\}e cells,

Volume of ejaculate multiplied by number of motilo gells per oubso centineter equels total number of moving cells in the ejaculate ("abalute motility")。

Fertllity bears a more direot relationship to absolute motility than to the conoentration of motile spermatozon per mlo of semen.

\section{Conoentration of Speratazos. A dilution of the semem is nade with a} fixing and staining solution which renders all colls imatile and eas1ly vialble。 A solution of methyl green is now in use, but other dyes are belng tested, The spermstozca count is made like a blood count on the red field of an haemocytometer, A 16 Iris, objective is used for countingo

The count of the fixed cells should not vary greatly from that of the motile and nonotile cells in the Locke ${ }^{\circ}$ s fluid preparation, and thereby serves as a check on the motile spermatorol sount.

$$
\text { Speed of Spernatozoa. In order to obtain some measurement of this }
$$

fertility factor, fize of the festest spermatoza in each of the f1ve blooks of aquares on the red field of the haemooytoneter are timed. The Locke"s flutd preperation is used for this detarmination, and the measurements are mede at DWETASSIFIED 
certain times after collection of the sample, the condition of temperature being kept congtant, The time for each of the spermatozos to oross a large square is determined by means of $\mathrm{a}$ atoprateh and the speeds of the 25 sperratozon are areraged. Only fast progressive spermatozor are timed.

It is to be realized that if the speed of spermatozen is deastionly reduced, sin eninal may be infertile despite the presence of large ntumers of motile spermatozod.

Both the type of motility and the apeed will have a definite bearing on the probebizity thet any one epermatozoon wilz ever find its way to an ovius.

The speed of rapid, progressive dog spermatozod seerns to be about the same as that reported by Farris far the human, $1_{0} \theta_{0}$, about 05 to 99 second for .05 15:L。 distance.

Charaoter of Motilityo Spermatozoa must not only move to complete fertilization, but they mast move with defintte formard progression.

Hormal spermatozo are usually the only ones which travel with definito formard progresston, but in all direotions from the point of deposit.

The oharacteristic types of motility which have been found are:

1. Progreasite (rapid, noderate, and sluggiah)

2. Oseillating

3. Gireling

Spermatogos with ovel heads uswally show progresstive type of motility。 The other spermatozoe, ropresenting various types of abnormalities, do not progress nomaliy as a rule, but are sluggish, oscillating, or moving in circlek. If a spermatozon camot mote progressively. it camot reach and fertilize an ovum. The speed must be adequate and the direction definite. Sperantozor whioh move sluggishly, oscillate, or more in airoles do not oontribute to fertility.

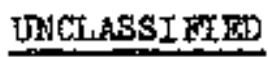




\section{DTCLASSIFIED}

Vorphologyo It is not posaible to classify semen speaimems without knowIng the importent oharacterfatios of the noridel spernatozoon under investigation.

A11 of the maie dogs produce some spermetozos thet are abnormal in apparance, and it is expected that the concentrationg of abnormal forma may rary wh irradiationo In the past in this leboratory increased numbers of abnornal spermatozoa, w1th abmortmel motility, have been noted following acute irradiation in rats.

By phese microsoopy and aIzo by means of norphologionl stains, the detalls of both active and inactire cella have been studied。

The normal dog epermatozoon has an ovel, somerinat flattened head, whioh in proftle te rather prriform in shape. The head is about 6 micra in Iength.

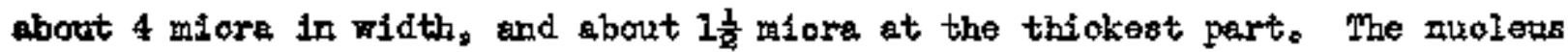
is In the posterior half of the heado A aap oovers a little more than half of the anterior part of the head.

The neok is alight congtriotion, about 妾 gnioron in length between the head and the middle piece.

The middle pioce is made up of a spiral filament of Ool mitoron or less in dameter, coiled about an axial fiber or thread to form a oylinder, the wholo being about 8 mâcre long and less then micron in diameter.

The tall tepers silghtly from the middiempiece to its terminal thread. The everage thickness of the tall appears to be about $1 / 3$ molon and its length sbout 45 micre. The tall has the appsarance of a $2 \mathrm{mgg}_{\mathrm{g}}$ smooth, floxtble structure with an external sheath, and showing slight density variations throughout its length. It has an abrupt temination, where its diameter is about 0.2 mioron, and its terminal filarnent, with a length of several microns, is about 0.1 mitcron thick, 
The abnormal cells are classified primarily by their variationg in ehapo, and zeem to be present in greater mubers in samples with low ooncentrations of spermatozon,

The abnormal forms notes are:

1. Giant hesds

2. Srall heads

3. Round heads

4. Double tails

5. Double heade

6. Separation of head and tail (tailless and headlens)

7. Eeads attached at abnomal angles

B. Oytoplasmio appendages

Three humdred individual oells ere examined under oil tmmeraion, are classified, and peroenteges of sbnomal forms aloulated.

Viability. A nigrosin-eosin stain for dfferentlating viable ano nonvieble apermatozea has been perfected to a point where it may now be used. Spermatoroa which are dead before application of the steln, take the statn. Spermatoroe which are alive at the time of applicetion of the stain do not take the stain.

Differential viabllity counts have been begw on our kemples.

How that menty of the technical problens of aocurate semed analysis have been met, this laboratory has begun to aooumulate quantitative control data whioh are considered to be dependable. When the aldest animale reach an unquestionable state of sexual maturity, probably well within a few months, irradiation will be started. Irradiation cannot be begin batiliy becauge the age at whith any dog begins exposure should be an age at which all dogs in the DNCLASSTFIED 


\section{UNCTASSIFIFP}

experinent will certeinly have reached sexual meturity by ald criteria used. It is felt neoessary to emphasize that data obtained until reoently on these young animels whioh were without, dering most the tims, adequete vtinuiation for true ejaculation of semen are considered too undependable and arratic for this report.

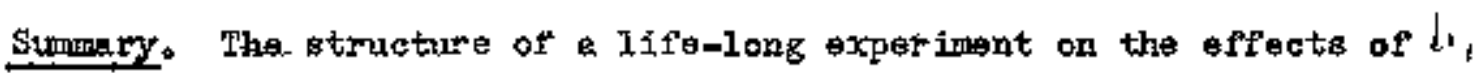
I-Irradiation on spermatogenesis in dogs hat been presented along with a desoription and discussion of the generel methods of aemen analyzis employed. Certain qualitative date have been reported but the incomplete and erratio data obteined on the immature dogs to dete are not dependable onough for reporting quantatively.

Froblem codez $\mathrm{X}_{0} \mathrm{R}_{0} 2$ (Hechantion of Befeots)

Section code: 3140

Author: B. H. Gabrio

A Paper Chrozatographic Stady of Ferritin acd Apofaxritin Hycrolysates.

Beckgroumd. Durfing the course of experimentation on some ohendesl properties of the iron-protein, fezritin, and the role of ferrtin it semed desirable to obtsin nore detailed information bbout the amino aeid conposition of ferritin, and its protein molety apoferritin. Conflicting data ooncerning the amino acid conponents of ferritin and apoferritin have been reported fram the laboretories of Kum et al (1) and Iria (2). Beoently, howover, Hezur and Shorr (3) reported the partial mino acld composition of horse spleen ferritin and apoferritin, which showed jdenticel amino acid ralues on the basis of aitragen contento 
DUCLASSIFEED

Esthods. The two dimensional chromatographio mothod used in these studie: was essentially that of consden, cordon, and Nartin (4) as modifiad by Dent (5). The solvents employed wore phenol, saturated with water, und a pixture of 2,4,6-0ollidine and 2,4-lutidine, saturated with wator. Fatman HI filter paper was used. The erino actds were detected by spreyling the papers with $0.1 \%$ ninhydrin in nubutanol to which exases of water had been added. The oolor was allowed to develop for 24 hours and the amino nolds were identisted by their relative positions and by comparison with a reference map prepared Dent (6). The chroratogram thus obtained with $50 \mu$. of horse spleen apoferritin hydrolysate equival ent to $0, B \mathrm{mg}$ of protedn is ghow in Figure $l$ (Pege 25). The hydrolysis pras oarried out with $6 \mathrm{~W}$ HCl at $100^{\circ} \mathrm{C}$ for 18 howrs. The following anino ackde were present as ninhydrin-resotive eubstancest tyrosine, phenylalarine, the leuoines, Filine, gluterio eosd, aspertio acid, glycine, serine, arginine, lysine, oystine, (as cystetc acid) and wathionino, Throonine was observed in trace smouts on chromatograns employing larger quantities of protein. Histidine Hes not oberved in Figure 1 because of ita lor sensitfitity to the ninhydrin reagent, although itg presenoe is reported hozur and Shorr (s). The relative quartftative estimations are in agreenent with those of Wazur and Shorr (3) except that in addition to those Issted by the latter authors, aspartio ackd, glyoine, serine, and threonine were deteoted chromatogrephically.

Paper chromatography of horge spleen ferritin shored the came amino coid oomposition as that of apoferritin, but in addition it wes observed that some of the iron, libersted by hydrolysis, had inigrated in the phenol direction as a definjte yellow spot. A chromatogram of ferrto tron alane did'not show this movement. It was found thet the rigration of iron on the chronatogrem of the 


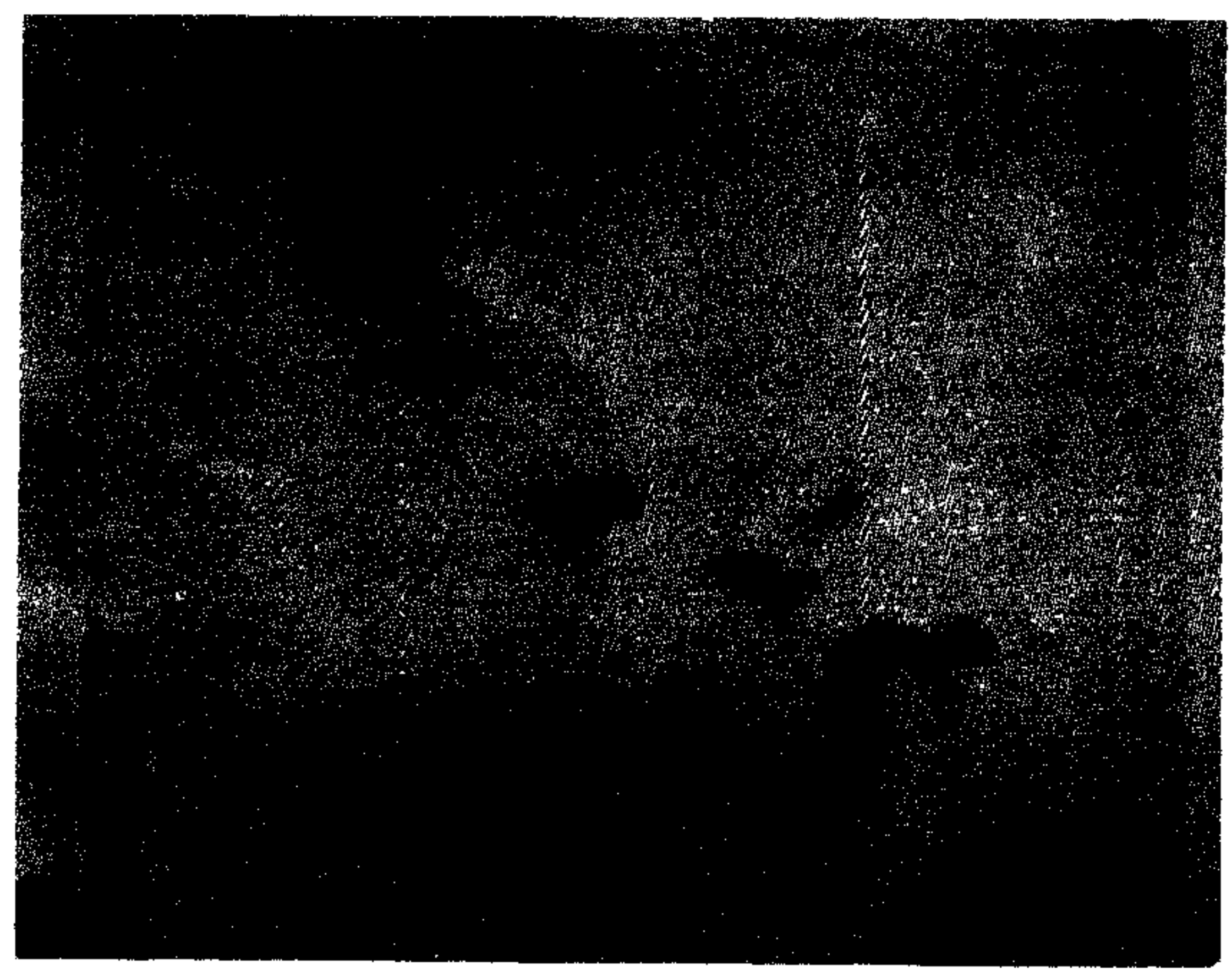

Mlgure 1. Chromatogran obtained wi th 50 po

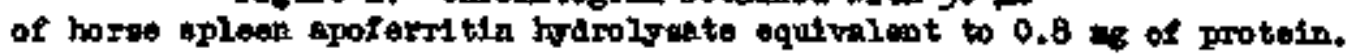


ferritin hydrolysate was not characteristic of ferritin, for identical morement was seen in a paper chromatogren mu on amigen (coumercial pancreatic casein hydrolysate) to which ferrio iron had been added in anounts epproxiruting that contained in ferritin. However, in all of these chrovetograns the arino acide moved to their relative positione with the oollidine-lutidine solvent while the iron reneined on the phenol absolesa. Thus the 1ron appears to be onjugated with ons or more of the arino acids in the phemol rim, but the essoosation is draxupted the oollidine-lutidize solvent.

One dimezsional chromatogramg (phenol solvent) of several single anino acids with added iron showed that all of the smino aclds testad wero apable of noving iron from the starting point in varying degrees. Feot arino aoti could be classified according to the amount of iron it carried. This information is tabulated belom in Table 1 . The system of grading of +4 to + is ised to designate the ancurt of iron carried by the enino acid.

\section{TAELE 1}

\begin{tabular}{|c|c|}
\hline Amitro Aoid & $\begin{array}{l}\text { Amomt of Iron } \\
\text { Carried by the } \\
\text { Amino Aoid }\end{array}$ \\
\hline $\begin{array}{l}\text { Histidine } \\
\text { Alanine } \\
\text { Arginine } \\
\text { Tsoleucine } \\
\text { leucine } \\
\text { Lysine } \\
\text { Phenylelanine } \\
\text { Tyrosine } \\
\text { Valine } \\
\text { Threonine } \\
\text { Serine } \\
\text { Aspartio acid } \\
\text { Glutanto actd } \\
\text { Glyoine } \\
\text { Control-iron }\end{array}$ & $\begin{array}{c}++1 \\
+ \\
+ \\
+ \\
+ \\
+ \\
+ \\
+ \\
+ \\
+ \\
+ \\
\text { No wigration }\end{array}$ \\
\hline
\end{tabular}




\section{ONCLASSIETED}

Thus, the iron spot, noted on the paper chromatograms of hydrolysed ferritin and anigentiron, is probably due to the fact that auoh amino ecids as histidine, the leuoines, arginine, iysine, phenylalentne, and raline are assooisted with a considerable anoumt of 1 ron and more to about the same position in phenol. It is also apperent from Table 7 (Page 26) that histidine ocofugates a greater quentity of ferrto iron than the other anino acids, Furthermore, the strong affinfty of histidine for iron has been reported (7). It is possible that a porralation might be found between the hiatidine content of proteina and thefr iron-biading oapaity.

Results. The amino acid composition of ferritin was studied by moans of twonimensimal chromatographis analysis. The ability of mino actda to carry iron was inventigated on a onerdinemsional ahrometograph.

\section{Bibliogrefing}

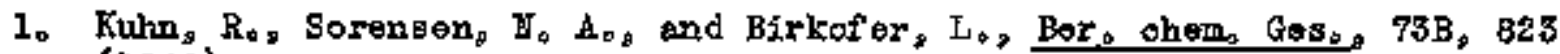
(1940)

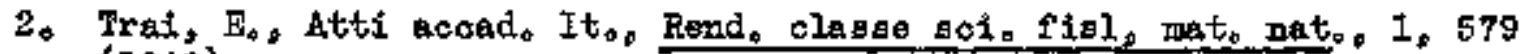
(1040)

3. Hasur, A, and Bhorr, Eo, Fed, Procos 8 , 228 (1949)

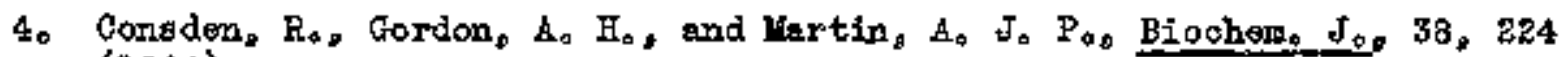
(1944)

5. Dent, $C_{0} E_{0}$, Biocherio $\mathcal{J}_{0}, 4 z_{0}, 240$ (1947)

6. Dents Co E⿱ B. Biochems Jo 43,169 (1948)

7. Thman, Jo Jrop Advenogs in Protein Chemistry, Acederato Press, 4, 410 (1948) 
Problean Code: X.R.3 (Therapy)

Section Code: 2608

Authors: $F$. Warth and $J_{a}$ Shrier

Effeot of Aureoryoin on Coaculation rime.

Background. It has beon reported that oertain antibiotic substances $(1,2)$ shorten the minole blood colgulation time, and a mecent referenoe (s) reports that aurecmyoin has a sinilar effeot. In stadies on the effoct of antibiotios on the radiation symdrom being esrried on in our laboretory it beceme of interest to determine if aureomgoin did have any effect on blood coagulation meohanitmso To this end the following experiments were done。

Hethod. A series of $81 x$ coagulation tines done by the lee thite the thod wth blood drewn from the externel jughiar vein were performed during a ono meek period, on four normal healthy mongrel dogs, A1l oodgulation timas are reported in alnutes. After these control values hed been obtained the dog: were given aurecanyoin capeules orally every $11 \mathrm{x}$ hourg, day and nighto for the next fifteen daye. The dose of aureomycin was approximately $300 \mathrm{mg} / \mathrm{kg} / \mathrm{K}$ hours (one $250 \mathrm{mg}$. oapsule $q_{0}$ aix hours) which is two to four tinge the recommended oral dose for hudans, Coagulation times were then done on these doga each morning approximately three hours after a dose of aureometin. The regultg are shorm in Table 1 below。

TABTE I

\begin{tabular}{|c|c|c|c|c|c|c|c|c|c|c|c|c|c|c|c|c|c|}
\hline \multirow{2}{*}{ Dog $10_{0}$} & \multicolumn{6}{|c|}{ Control Days } & \multicolumn{11}{|c|}{ Days After Starting Aureonyoin Adnefnt stration } \\
\hline & $?$ & 2 & 3 & 4 & 5 & 6 & 1 & 2 & 3 & 4 & 7 & 8 & 9 & 30 & II & 14 & 15 \\
\hline \pm & 7 & $\ddot{b}$ & 5 & 9 & 9 & 8 & 8 & $1 I$ & 9 & 8 & $\mathrm{~g}$ & 10 & 10 & 11 & 10 & 10 & 6 \\
\hline 2 & 7 & 8 & 10 & 9 & 20 & 9 & $\mathbf{I I}$ & 12 & 9 & 9 & 8 & 21 & 10 & 12 & 10 & 11 & 9 \\
\hline 3 & 7 & 7 & 13 & 12 & 10 & 10 & 21 & 13 & 10 & 10 & 10 & 13 & 7 & 10 & 9 & 11 & 3 \\
\hline 4 & 10 & 8 & 10 & 8 & 12 & 11 & 11 & II & 10 & 10 & 5 & 8 & 11 & 11 & $g$ & 8 & 6 \\
\hline
\end{tabular}




\section{DLCLLSSSI FIED}

Serum levels of eureampin were done on these dogs on three peossions and found to be between 2 and 16 miorograms/oo (averaging $5 \mathrm{mcg} / \mathrm{cc}$ ) which corers the range of levels reported in humens recelving exreomyctin. The effect on the cosgulation time of $\mathrm{g}$ single, tery large oral dose of surecmgetn (200 mg/ $\mathrm{kg}$ ) is shom in Table 2 belon.

PABLE 2

\begin{tabular}{|c|c|c|c|c|c|}
\hline Dog No. & Control & Control & Control & $\begin{array}{c}2 \text { Houra } \\
\text { After Aureoryotin }\end{array}$ & $\begin{array}{c}3 \text { Hours } \\
\text { Artar hurecongcin }\end{array}$ \\
\hline 1548 & 10 & 9 & 8 & $\theta$ & 8 \\
\hline 1505 & 10 & 7 & 6 & $\theta$ & 10 \\
\hline
\end{tabular}

It was also of interest to know if intravenous aurecmyoin had any effect on cogulation time。 Fith this route of administration higher and more prolonged arum levels of aurecryoin can be obtained. Seven normal healthy adult mongrel dogs were used for this experiment. A series of thres control congulation times were done on each dog during a period of thirty minutes previous to

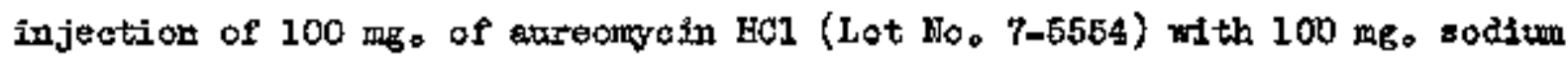
glycinate dissolved in 20 oo of sterfle normal allne. This solution was Injected fn the external jugular vein over a period of aixty seconds, coagulation times mere taken on the dogs at intervals after injaction, and the results are shom in Table 8 (Page 30 ) a

An atteipt was made to determine if aurecanycin had any of feot on ooagulation time in vitro loasured quantitles of auracryoin buffered with aodsin glycinate and dissolved in $0,5 \mathrm{cc}$ of saline were placed in the suell tubes used for the oogulation time. Thole blood drawn from a norms d dog was placed in these tiabes and the time for coagulation to oocur wes measured. 
TABLE 3

\begin{tabular}{|c|c|c|c|c|c|c|c|c|c|c|}
\hline \multirow{3}{*}{ 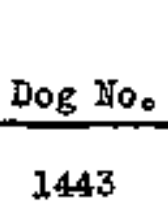 } & & & & \multicolumn{7}{|c|}{ Time After Aureomyoin Adninistration } \\
\hline & \multicolumn{3}{|c|}{ Controls } & 15 min. & $30 \mathrm{~min}$ & 1 hour & 2 hours & 8 hours & 4 hours & 5 hours \\
\hline & 6 & 8 & 7 & 604 & 60 & 60 & $60_{+}$ & 30 & 10 & 12 \\
\hline 1445 & 10 & 10 & 9 & 10 & 10 & 9 & 8 & & & \\
\hline 1286 & 8 & 3 & $\mathbf{5}$ & 3004 & $285+$ & $240_{\phi}$ & 1804 & 30 & 21 & 6 \\
\hline$\$ 498$ & 4 & 4 & 3 & $120+$ & 52 & 19 & 7 & & & \\
\hline 1584 & 11 & 10 & 5 & 2 & 3 & 7 & 8 & 9 & 8 & \\
\hline \pm 480 & 10 & 8 & 3 & 3 & 3 & 8 & 8 & 8 & 8 & \\
\hline 1530 & 8 & 9 & 3 & $240+$ & 2404 & 1954 & 70 & 16 & 7 & \\
\hline
\end{tabular}

The regults are shown in Table 4 belor.

TABLEN 4

\begin{tabular}{|c|c|c|}
\hline & Trial No. 1 & Trial No. 2 \\
\hline Control without apline & 6 & 10 \\
\hline Control pith seline & 17 & 10 \\
\hline Aureouyefn $5 \mathrm{neg}$ of $/ \mathrm{cc}_{0}$ & 15 & 23 \\
\hline Aureomyoin $10 \mathrm{mcg} / \mathrm{co}$ & 15 & 11 \\
\hline Aureountotin $200 \mathrm{meg} / \mathrm{Oc}_{0}$ & 15 & \\
\hline
\end{tabular}

Disousatone According to the expertments reported here oral aurecinycin in therapeutic doses has no effect on the whole blood opagulation ting. As shown in Table 3 aborg the intravenous adginiatratiog of aureoaycin in this dosage produced a marked prolongation of the coagulation time in four of the geverl dogs. Hot of the doge which showed prolonged coagulation time, also 
exhibited a shock-1ike state for flve to flfteen minutes immediately after injection which was charecterized by lethargy, staggering gait, and toniting. It was felt that this represented a "peptone shock" phenomenon and that a heparta-like substance was raleased into the blood by the some reaction (4)。 It was not determined whether this was due to the aureanyoin HCl, or the sodjum glycinate used as a buffering agent. In an attempt to deternine this by adrinistering an equal quantity (200 mgo) of alreomyoin HCl without buffer intravenously such profound hemolysis ensued that gross hemoglobinuria occurred and the dog succumbed wthin 48 houra sfter injection. The admintiptration of such a concentrated solution of aureomycin HCl-sodiur glycinate in a reletively short period of tine nasy also have provoked the shock reaction. The mixing of gureomycth with blood after it was drawn had no apparent effect on the ooagulation time

\section{Concluatons.}

1. Aureomyoin administered orally in amounts which produoe therapeutic blood levels, bas no effeot on the whole blood coegulation time In dogs。

2. Intravenous aureomycin HCl buffered writh sodium glycingte may produce a markediy prolonged ooagulation time. This effeot may be related to a "peptone-shook" phenomenon.

3. In vitro, aureomycin hes no effect on the blood oosulation time.

\section{Bíbliography}

1. Hacht, Do $I_{0}$ Sclence, 105, 213 (1947)

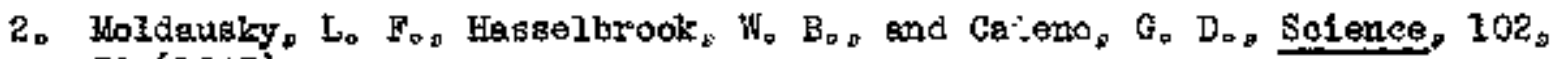
$38(1945)$

3o lacht, $D_{0} I_{0,}$ and Farkas, $R_{00}$ Scïence, 110, 305 (1949)

4. Jaques, $L_{0} B_{0}$, and Water $B_{0} F_{0 s} A_{0} J_{0}$ Physiology $129_{0} 389$ (1940) 
Problem Code: $\bar{X}_{0} R_{0} 3$ (Therapy)

Seotion Codes 2606

Authorat F, U. Furth and Y. Coulter

Effect of Aureomyoin and Terrangoin on the Nortality and Diarrhea of the x-radieted Rat,

Beokground, Freliminary expertments dome fin this seotion during the past year indicated that aertajn of the antibiotio and chenotherapertio agents are effective in reducing the incidence of diarrhea and possibly affect the mortaltby of rats which have received large doses of whole body x-radiation. These experiments have involved the use of a variety of therapeutic agents including pensozlitn, streptomycin, ohlorenphenical, and several sulfonamide corpounds. Bone of these were found to influence the morbicity end mortality of the x-radiated rat as favorably as aureauyoin and terramycino Although earlier experiments with these two druge involving smaller groups of rats have been done, only the most recent experiment which shows results typioal of all the experiments will be reported here.

$\therefore \quad$ Method. A total of 180 adult female Wister rats reighing 160 - 180 gms. were used in this experiment. They wore divided into 4 groups of 45 ouch.

Each rat was housed in an individual oage. The rets wore weighed, and exempined for ovfdenos of diarxhea, dally for 7 deys prior to radiktion. Theale tome obterrations were continued for 28 daje post-radiation, taoh rat was offored '15 grame of feed oach day, and the anount left from the previous day bas 11 reighed so that a measure of the eppetite could be made. Those rats mich received the drugs were offered is gas of feed dally with whitob the drug had besi admixed. The groups which roceited the drug in the feed only were 1

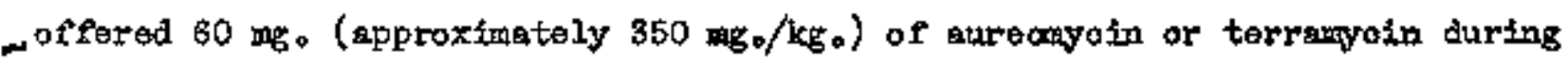
ㅁNCL.ASSIFIBD 


\section{DNCIASSIPI I HD}

the first 5 days post-radiation vinen the anorexie mas most Herked Theresfter whil the 28th day post-radiation they were of fered 22.5 ang. (approximately $100 \mathrm{mg} / \mathrm{kg}$ ) of the drag each dayo $50 \mathrm{mg}$ of of aureomycin-sodjum ty yoluate was added to the drinking water of one group for the first 5 days post-radiation and the amougt of water trunk during each 24 hours measured. These rate trers also offered 22.5 mg. of aureamyin in the feed each day during the entire post-radiation period. sll the aruga were started inmediately after radiation. The rats mere given a total of 700 I of whole body $x$-radietion at the rate of $18 \mathrm{r} /$ minute adninistered by a $250 \mathrm{KV}$ Picker machine at $15 \mathrm{~m}$. a parabolic aluminum filter and 0.5 mo of copper. The target skin distanco was 25 1nches. They were radiated in groups of 15 which wart arranged to include rats from expheringatel groupe

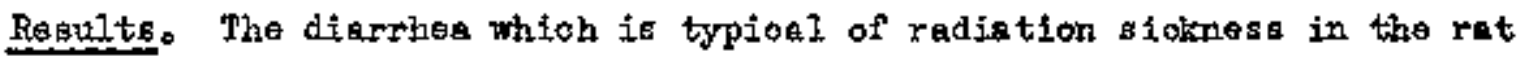
appeared on the third day post-radiation. In the control group the percentege of rats with diarrhea was zuch higher than many of the treated groups, as ghown in Graph 1 (Page 34). Coincident with the diarrhea was a profound anorexia and weight loss, This anorexig and weight loss res equally serere In oontrol and treated groups until the 5 th day posturadiation when the trasted groups began to eat more and regein weight more repidly. The surviving treated rats regained their pre-radiation weight more repidly than the surviving control rats. The rats in the groupe which receltred aureomyoin and terrardycin In the feed presented better apperance during the first ten deys post-radistIon wif smoother coate and greater activity. The mortality in the group witch received the aureanyein only in the feed approxinated that of the controls as shown in Graph 2 (Page 35). In the group which recelved supplonentary aureosycin in the driaking water the rate of mortality and 28 day mortality 
GRAFH 1

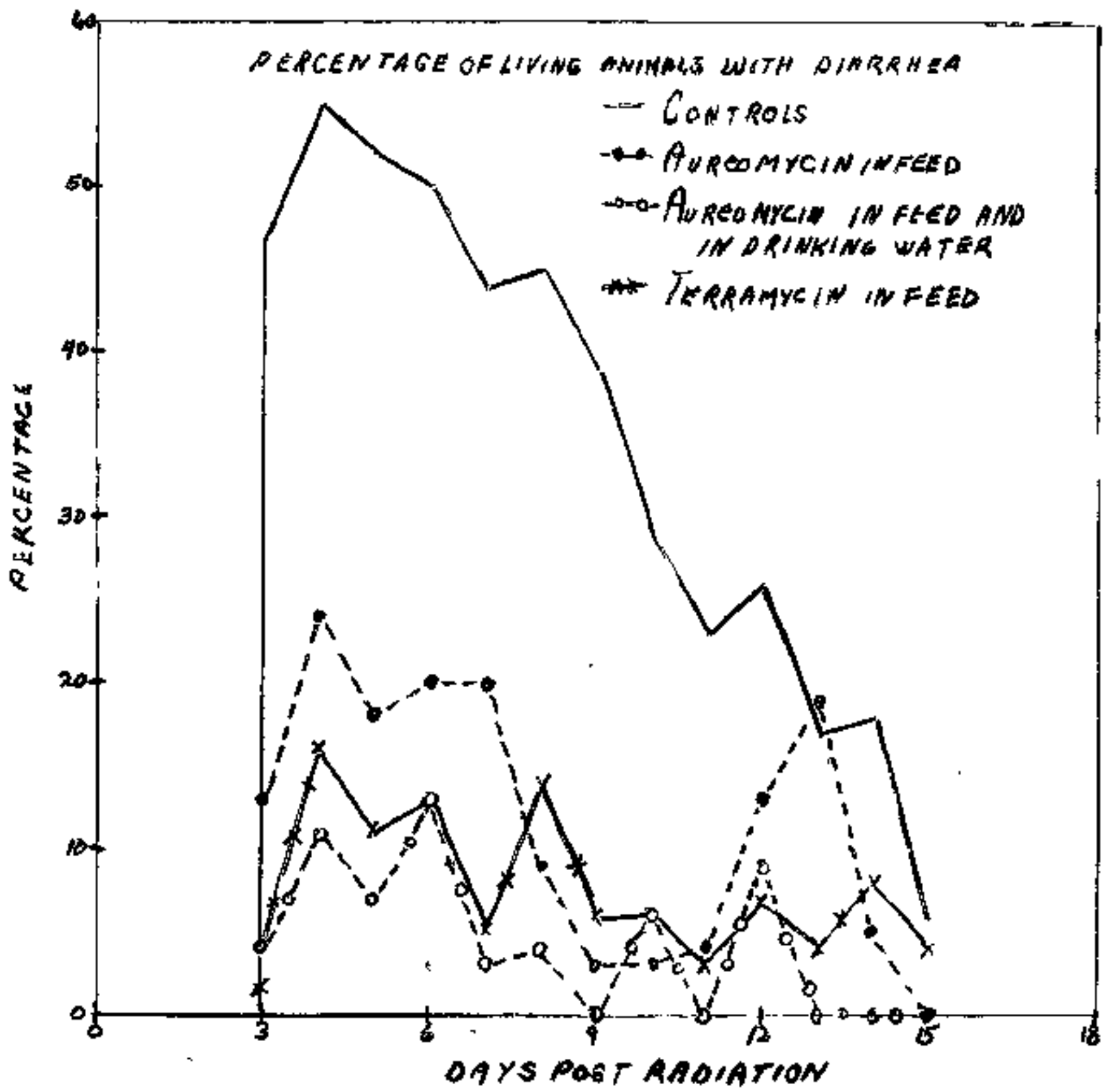


35.

THCLASST FLED

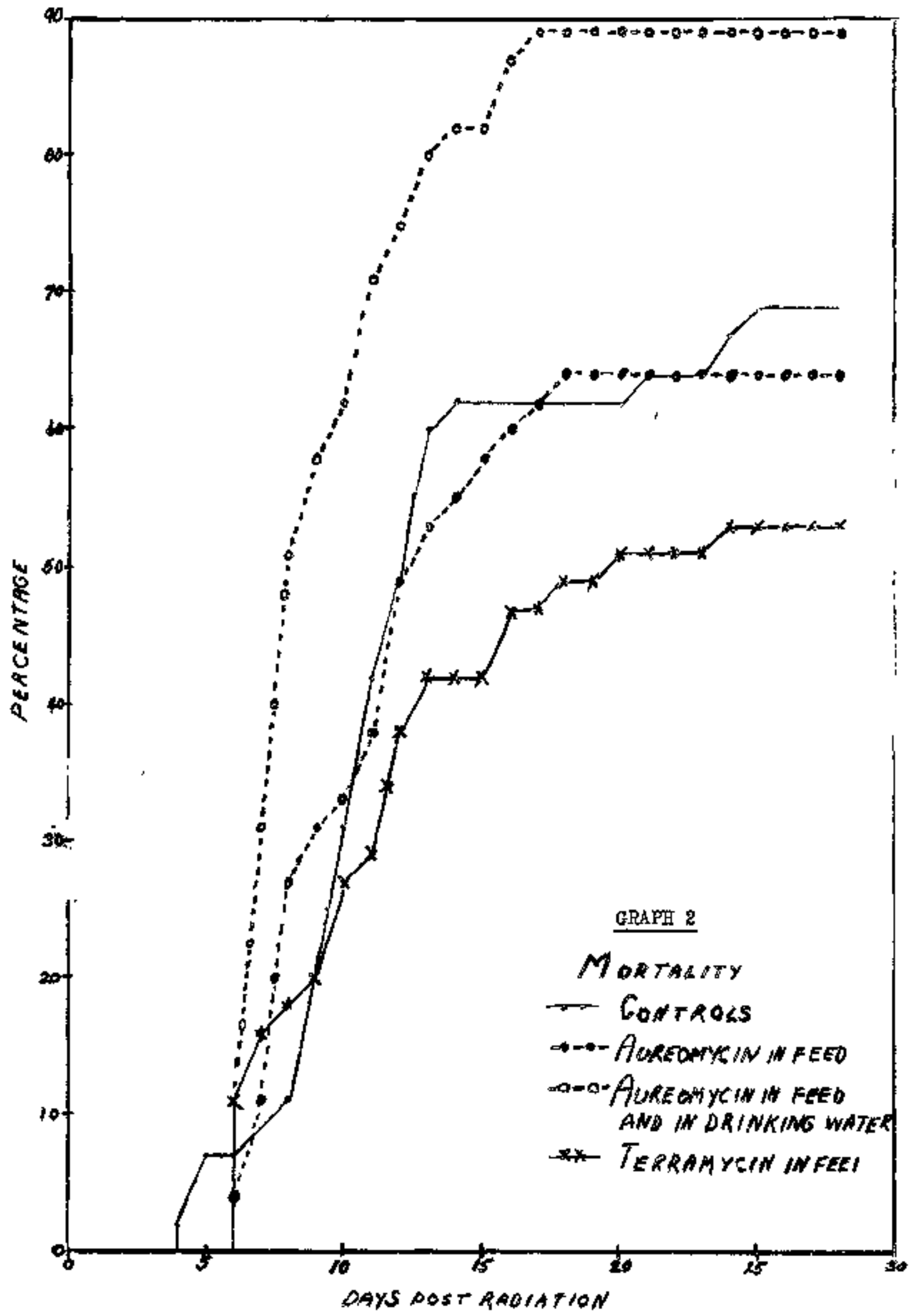


was higher than in the control group. The terreangin-treated group showed a sortality which was less than the controls。

Diseussion, The decrease in diarrhea associated with the edminfotration of aureomyoin and terrantycin to the x-radiated rat nay heve several explanatlons. Since both of these drugs are potent entibiotics, effective against both grampositive and gram-negative orgensam, it is conceivable that the buik of the feoes may bo diminished by deoreasing the numbers of bacteria within the gastro-intestinal traot. It 1a also possible that this docrease in bacterial flora mey diminish the frritating effect that the bacteria may have on the Injured epithelium of the gestro-intestinal tract. It is also possible that thic decrease in bacterial flara maj diminish the frritating effect that the bacteria may hare on the injured epithalfum of the gastrosinteatinal tract。 The possibility that either of these drugs may exert a speoific inhibitory effect of peristalsis through parasympathetlc paralysis soems remote since we have foumd that other antibiotics such as penicillin and streptoryeln also diminish the diarrhea following $x$-radiation in the rato The oause of the more rapid regain of woight in the treated rate may in part be explained by the alteration in intestinal fora. It has been recently reported ( 1$)_{0}$ that gureomycin fed to normal rats causes augmented weight gain and growth but an edequete explanation of this phencunonen hea not been advanced. Miller and his co-morkers (2), report a markedly diminished portality in x-radiated mioe given streptomyotn and/or terramycin. They also report (3) that the incidence of positive blood oultures in $x$-radiated mice can be reduced by the adnintatration of these antibiatics. Tis have been ungble to substantiate these results In rats as far as mortality is concerned using gtraptomycin, aureculvein or terrampein. In this experiment terrenycin segmingly did decresse the mortality. INALLASS IFIED 
It may be that if blood stream infeotion plays a role in the mortality follow ing x-radiation in the rat, there existg an organism in our strain of rats which is reslstant to the antiblotice loed and whion may produce generalized sepsis and death. Studies on the beoterial flara of the strain of rats used. In these experiments are contemplated. The fncreased mortality in the group which recelved the eupplementary aureomyoin in the drinking weter would seem

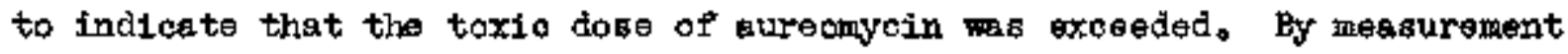
the rats reosived no more then 25 mgo of aurearyein per dey ( $160 \mathrm{mo} / \mathrm{kg}_{0}$ ) which does not exceed the oral toxic dose reported (4) for rats, However, the injured epithelium mat be more permesble and allow a toxic ennount of aureculycin to be absorbed. This may in part account for the sbsence of effeot on mortality observed in the doga In addition, following $x-r$ adiation the normal detoxification mechanisms may be altered, so that smaller doses may produce toxiolty.

\section{Stumaryo}

1. Orally administered eureanycin and terranyein merkedly diminishes the incidence of diarrhas in the ret which has recefted a lange dose of whole body x-radiatton.

2. Oral aureamycin and terramyein accelerste the regain of weight following xradiation in the rato

3. Oral terremoin may diminlsh the mortelity following large doses of $x$-radiation in the rat.

\section{Bibliogreghy}

1. Parkonal comminication - So H. Hardy, Lederle Laboratorles

2. Hiler, C. Philifips, Hammond, Carolyn Wfo, Tompkins, Harlanno, Seienoe, $111,719(1950)$ 
3. Ibtd, Science

4. Harnod, B. $K_{n}$, et al, Ann, $\mathrm{H}_{0} \mathrm{Y}_{0}$ Acad, Boience, 51,182 (1948)

Problem Code: $X_{\phi} R_{0} 4$ (Hemstolog

Section code: 3352

Authors Mo Ingram

The Inoidence of Dnusugl Lymphocytes in the Blood of Dogs Exposed to Radintion

from the 130-inch Cyolotron.

Previous quarterly Reporta have indicated that the relationshlp betmeen the inajdence of lymphooytee with bilobed nuolei in the peripheral blood and exposure to radiation from the oyclotron was being stadiot in an expertinant utilizing dogs。 Specifieally, three healthy fongrel doge have been studied before and sfter three different expoelures to small amounts of radiation from the 130 inoh oyolotion. Quantitative interpretation of the experimental results ia now essentially complete and it is possible to report additionel $i$ details of the relationship between the exposures and the fncidence of the abnoral oells.

The entire experiment extanded over perlod of epproximately one yeer. Blood axaminationg were de approxjmately daily during a control poriod of approximately tro months prior to the firgt exposures During this period a total of 180 ooteralip blood smears was examined. A like number was exenatned during each first post-exposure velk, and ther anter approximately 30 ameare mere examined each week.

For conventenoe in laterpreting resulta exoh blood buear has been clessified according to whether or not it ocmtalna one or mort of the abuomal DHCLASSIFIED 
Iymphooytes, and the frequency of ocurrence of "posititen smears has arbitrarily been ohasen as an index of the Incidence of lymphocytes with bilobed naclei. In all, epproximately 8.4 × $10^{6}$ wite blood cello were examined during the entire experimant。 The experinental results are progented briefly in Table 1 (Page 40). They indicate a marked inoresse in the ocourremoe of 1ymphooyted with bllobed melel following expostre to radiation frot the ayolotron. The Incidence we merimal during en approximately tho-week perlod following each of the three expostures. Thereafter the Inoidence deareased fatrly ateadily. The dightly higher frequency of positive blood smears after the flrst exposure probably indicates that a greater doge of radiation was recaived in that expoeure, This asamption is supported by the fact that a sifight but definfto decrease in the white blood oell oomts oocurred conoomitantly with the increased incidence of lymphocytes with bilobed mulei in this instence. Ho reduction In the total leukooyte count was noted after the second and thind exposurea. At this time it is not possible to ind cete the relative effectiveness of the rarious oomponents of radiation from the cyolotron in inducing the Itoreaged Inoidence of the unusual lypphoytes, however studteg designed to proytde such Information are ourrently being undertaken. 


\section{TABLS 1}

FREQUENCY OR BLOOD SURARS" CONTAINING OHE OR MORE LFMPHOCYTES WITH BILOBED NUCLEUS

(Doga exposed to radiation fren $130^{\text {th }}$ cyolotron)

\begin{tabular}{|c|c|c|c|c|c|c|}
\hline & \multirow[b]{2}{*}{ Control Period* } & \multicolumn{5}{|c|}{ Postwexposure Period } \\
\hline & & lst week & 2nd woek & 5rd \& 4th weeks & 5th * 6th meiks & After Bth roek \\
\hline Iat exposure & $0.00(6)$ & $0.22 * *$ & $0.37 * *$ & 0,11 & 0.02 & - - \\
\hline and exposture & $"$ & 0.16 & 0.13 & 0.06. & 0.03 & 0 \\
\hline 3rd exposure & n & 0.18 & 0.07 & $0.11 \#$ & $=-$ & .OBN- - - - \\
\hline
\end{tabular}

* Control counts represent a period of approxinately two monthi before the first exposure ** Associated with a slight depresston in the total wite blood oell oumt

\# Counts were done only onoe week after the third week, and only three days during 3rd week

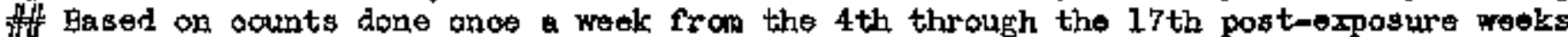


41.

PROGRAII U。

URARTUH

Problem Code: 0 of (Fate)

Section Code: 3210

Authors: $H_{0} F_{0}$ Stokinger, $H_{0} E_{0}$ Hilson, $G$, $F_{0}$ Sylvester and $S_{0} P_{0}$ Dzuiba*

Lobay Partition of Inhaled $\mathrm{U}_{3} \mathrm{O}_{8}$ Particles.

A rovier of the toxfcologic literature on the deposition and retention of pertioulate matter reveals considerable information on the anount of (1) deposition in the entire respiratory system: (2) nasel filtration and penetrations (3) alveolar doposition - as a function of particle size, shepe, solubility. breathing rate and other factors in the human and laboratory animal.

This information has uncuestioneble merit in definfing the amount of conteminant of knom characteristics that will be retained on inhalation and where particles of a given aize may be expeoted to lodge in the respiretory treeg but it is insufficient to form a sound basts for evaluation of more localized tlssue injury from the inhalation of chemically toxic or radionctive particles at any particular site in the lumgo Previous data assume a unformdeposition of partioulate matter throughout the luggo

The present study was undertaken to supply quantitative information as to whether an evon distribution of dust oocurred uniformily in all lobes and in gross seotions of the longs inder normal conditions of inhalation in animals.

Propedureg Twoty albino rata of sfmilar age and wofght (261-514 g) were exposed in individual, corpartmentalized cages continuously for one, 6-hour period to $\mathrm{J}_{3} \mathrm{O}_{\mathrm{g}}$ dust of known particle eize. The massunedian size dotermined by

* With the teohnicel assistence of $\mathrm{R}_{0} \mathrm{E}_{0}$ Root 
Gascade Impactor sasiples of the exposure atmosphere was 266 with a standard

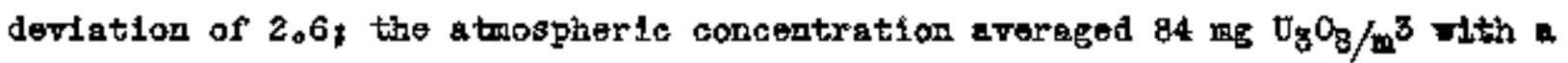
range of from 80mat as sampled by the filter paper dust ampler with a Fhatman \$42 paper and quantitetively determined by acid rerrocyanide.

In order to allom opportunity for the pertifoles to be oleared from the larger air pagsages (1), the rats were not cilled until the following morning. The group of 20 rate ras ditided at randan in 2 groups of 10 eaoh; from one group of 10 rata, the lumg was divided into its 5 natural lobes, namely, lafto post-oaral, supertor, medtan and inferfor left lobeg, from the other 10 rats, 3 equal, transverse soctions were taken from each rat from the left lobe which wo termed the tppers middle and lower sections. The weight of each fresh section was detenringd to the nearest rilligrar on an analytion balenes the body wights of the rats were obtained at death in order to permit oonparison of the lunt to boty wight, witich ralue gives en fradication of the oudition of the lug . Analyses for urantum were made in quadraplfoate by the fluorophotometrio method of ferman (2) and the results antlyzed statistically by Dr. S, Lee Crump. Regults. The uramim amalyses fn $\mu \mathrm{g} \mathrm{V} / \mathrm{g}$ freth tissue of the 5 lobed and transverse sections with the respeotive rat bodyweights are given in Tablos 1 and 2 (Fage 43). It is epparent from these tables that partioulate araniun is deposited in the upper right lumg lobe in from $1.5-2$ times the anount of that found in ang other lobe on a concentration basid. Ho differences in depasition axong any ather lobes were found. The differenoe in deposition cantot be due to differences in lobar size as the upper right lobe is as emall as sur other seotion in the rat lomg (Table 3, Fege 44).

Then tables utflizing the date of Tables 1 and 2 wore prepared to ascertain whether the aroumt of urenium in the seguents were determined by 
TABAD 1

FARTI TION OF IRTAL, FT $\mathrm{U}_{3} \mathrm{O}_{8}$ DUST IN LDISS OF BATS

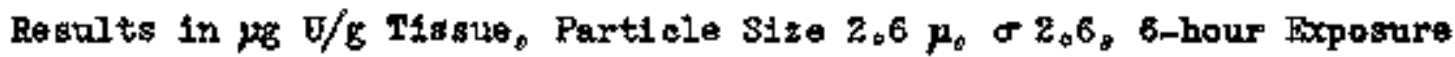

\begin{tabular}{|c|c|c|c|c|c|c|}
\hline $\begin{array}{l}\text { Ret } \\
\text { Io. }\end{array}$ & Left & $\begin{array}{l}\text { Post Cuval } \\
\text { (Hedtan) }\end{array}$ & $\begin{array}{l}\text { Upper } \\
\text { atght }\end{array}$ & $\begin{array}{l}\text { Yodian } \\
\text { Right }\end{array}$ & $\begin{array}{l}\text { Lower } \\
\text { Right }\end{array}$ & $\underset{\text { Rat }}{\text { Raghts }}$ \\
\hline $\begin{array}{r}2 \\
7 \\
9 \\
11 \\
13 \\
14 \\
16 \\
17 \\
18 \\
19\end{array}$ & $\begin{array}{l}19.6 \\
23.8 \\
18.8 \\
16.1 \\
23.0 \\
31.7 \\
18.8 \\
32.0 \\
20.9 \\
32.4\end{array}$ & $\begin{array}{l}13_{0} 2 \\
23.9 \\
27.4 \\
12.2 \\
24.3 \\
33_{0} 9 \\
16.2 \\
27.9 \\
21.0 \\
31.4\end{array}$ & $\begin{array}{r}9.1 \\
41.7 \\
40.5 \\
23.2 \\
36.3 \\
54.2 \\
32.7 \\
50.0 \\
30.7 \\
47.0\end{array}$ & $\begin{array}{r}4.7 \\
22.0 \\
29_{\circ} .2 \\
12.2 \\
21.9 \\
27.3 \\
16.5 \\
24_{0} 4 \\
20.4 \\
28_{0} 5\end{array}$ & $\begin{array}{l}15.0 \\
21.1 \\
25.4 \\
13.2 \\
21.1 \\
30.8 \\
13.8 \\
31.7 \\
12.6 \\
34.8\end{array}$ & $\begin{array}{l}295 \\
275 \\
296 \\
268 \\
281 \\
282 \\
281 \\
258 \\
273 \\
393\end{array}$ \\
\hline $\begin{array}{l}\text { Sün } \\
\text { AT. }\end{array}$ & $\begin{array}{l}237_{\circ} 1 \\
23.7\end{array}$ & $\begin{array}{l}231.4 \\
23.14\end{array}$ & $\begin{array}{l}365.4 \\
86.54\end{array}$ & $\begin{array}{l}207.9 \\
20.79\end{array}$ & $\begin{array}{l}219.4 \\
21.94\end{array}$ & \\
\hline
\end{tabular}

TABISE 2

PARTITION OF INHALAD $\mathrm{U}_{3} \mathrm{O}_{3}$ DUST IN TRABSVERSE SECPIOM OP LEFT LOBE OF LUNG OF RAPS

Resulte in $\mu \mathrm{g}$ V/G Tisene, Particie Size

$2.6 \mu, \sigma 2,6,6$-hour Exposure

\begin{tabular}{|c|c|c|c|c|}
\hline $\begin{array}{l}\text { Rat } \\
\text { So。 }\end{array}$ & Dpper & Kiddle & Iower & $\begin{array}{c}\text { Eat } \\
\text { Weights }\end{array}$ \\
\hline $\begin{array}{r}1 \\
3 \\
4 \\
5 \\
6 \\
8 \\
10 \\
18 \\
15 \\
20\end{array}$ & $\begin{array}{l}28_{0} 3 \\
30_{\circ} 0 \\
20_{04} \\
22_{\circ 0} \\
27_{03} \\
44_{08} \\
19.3 \\
18_{08} \\
30_{06} \\
45_{0} 8\end{array}$ & $\begin{array}{r}21.5 \\
32.6 \\
4.6 \\
16.8 \\
22.6 \\
37.7 \\
11.8 \\
32.8 \\
26.7 \\
34.3\end{array}$ & $\begin{array}{l}25.0 \\
33.5 \\
18.9 \\
22.9 \\
22.6 \\
48.7 \\
26.6 \\
12.7 \\
28.4 \\
37.2\end{array}$ & $\begin{array}{l}312 \\
314 \\
261 \\
279 \\
305 \\
275 \\
300 \\
295 \\
285 \\
267\end{array}$ \\
\hline Sum & $2 \mathrm{BO}_{0} 4$ & 241.4 & 276.3 & \\
\hline$A v_{0}$ & 28,04 & 24.14 & 27.63 & \\
\hline
\end{tabular}




\section{TABLE 3}

AVFRAGR LOBE WEIGHT OF RATS*

(in milligrams)

\section{Post Ceval}

UPPER RIGHT

Median Right

Lower Right

Left

\section{4}

136

172

385

$43 B$

* Rat woights arreraged $280 \mathrm{~g}$

eithers (1) the tissue mass of the esgments; or (2) by the lung weight end body weight as cowrariants, no oorrelation of either sort was obtatned Mareover. lumg woight to body weight shomed a ratio of all specirens bel ow $0.6 \%$ indlcating no pathologic process we pregent that might influenos the resulte; the normal luas to body welght ratio averages $0.5 \%$ for rats of our colong, The fimportenoe of finding differences in lobar deposition is obrious in perritting a better estimate of tisaue infury from inhaled particulates eapecially of radioactive character.

\section{Conolusions.}

1. A non-miform deposition of partioles of massmediem size 2.6 p has besn demonstrated in the lung of the rat after single, 6-hour inhalation of $U_{3} 0_{8}: I_{0} 5$ to 2 thes as much mes deposited in the upper right lobe as in any other lobe of the ling.

2. Deposition was uncin in the othir 4 lobes。

3. No appreoiable differenoes in daposition were found in grose, trensverse Bections of the large left lobe. 


\section{B1bllographr}

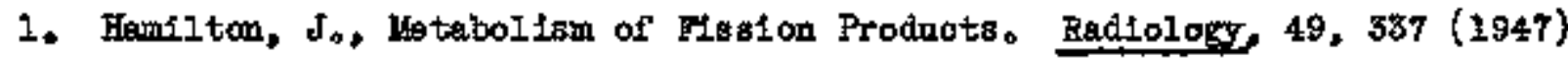

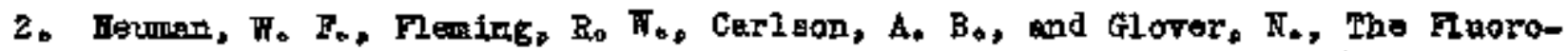
photometrio Determisation of Jranium fn Blologfoal laterial. Jo Blol, Ghem, $173,41(1948)$

Problem Code: $\nabla_{0} 4$ (Fate)

Section code: 3210

Authors: C. W, LaBelle and $J_{0}$ K. Dohl

Redioactive Dast as a Pracer in the Study of Iomg Treasport Meahanisns. Io Ansirtiosl Kethods.

A asmple of radioative dust is avallable whioh it fs believed will facilit te the study of the transport of particulate material within the lung, provided that an assey mothod can be developed. The two requi rewents for moh an aseay sothod are first, that it be aufficiently rapid to peralt mosurement of a lerger mmber of senples per day, and seoond, that it fnroive no assumptiong as to the chenlcal species asoosiated With the redioactivity, especially with respect to the solution and trangfer of emples. The precision of the method, although important, is secondary to these other requirementia As a corollary requirement, It is degirable that the sagng mothod be suoh as to pormit Eecontemination of the apparatus and oonteiners used in the process. It is believed that the thats deasribed belor offer satisfactory solutions to the se problems.

Exporimentel. Prelintnary tests showed that the following technique is 'adequate for the destruction of organio matter in a biological sumple of the sise contemplated, and in addt

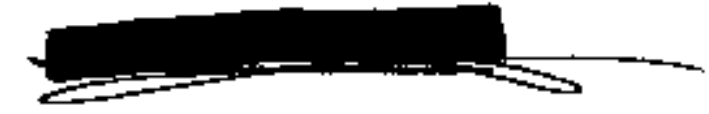


46.

ntmbers of samples with alinimal attention.

The semple, weighing up to 2 grams on the wot basid, is renovod from the

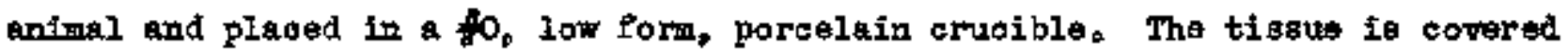
rith concentrated nitrito acld of which the rolume may be raried to sult the alize of the sample taken, and allored to stand overnight, At this point the aracible oortaing a olear jollow 11quid wh only an ocassional fat globule remaining of the original tissug, This 1,1quid is eraporated at a los temperetare $\left(70-90^{\circ} \mathrm{C}\right)$ to a pasty residue whioh 1 a pinally oharred on a hot plate until no more nitrous fume is seen. The crucible is them placed in a framace at 700 7500 for one hour, at which tine the ash 5s normally coupletely solorlegs or at least free of umburned carbon.

An edaptor was construated by which orucibles oould be inserted into the shtelded counting ohamber in such a way that the upper $r$ in of the cructble ocoupled the position normally ocoupled by the foils used in conventional cotmt ing techniques. One milliliter of radi oagtive dust suspemaion was pipotted into each of nine oruofiles, eraporated to dymess and comted, Each oruafble was then remeraporated with one milliliter of distilled water, ovaporated with 5 mililiters of conoentrated nitrio aoid and finaliy ignited for me hour at $700^{\circ} \mathrm{C}$, counting each cruaible betwen each operation ${ }_{o}$ Finally, series of nine foils wre prepared from one milifiter samples of the original suspension, dried and counted in the conventional manner. The rosults are show in Table 1 (Pago 47).

The differendes between folls and cmucibles are due rostly to the ofmpletely different geometries 1nvolved in the two methods of conenting sond are no greater then inight be expected. The difference between the cructbles before and after the ohemical treatment represents se shift. of $\frac{3602-3343}{\sqrt{192 \times 297 \times 9}}=3.4$ 
TABLE 1

USE OP POREHLIN CRUCTBLES AS BAMPLE CARRTEFS II 9 SAMFLES

\begin{tabular}{|c|c|c|c|c|c|}
\hline & \multirow[b]{2}{*}{ Boila } & \multicolumn{4}{|c|}{ CKUCIBLES } \\
\hline & & $\begin{array}{l}\text { Oresgo } \\
\text { Count }\end{array}$ & $\begin{array}{l}\text { Eraporated } \\
\text { with Tieter }\end{array}$ & $\begin{array}{l}\text { Eraporated } \\
\text { rith Aold }\end{array}$ & $\begin{array}{l}\text { Ignfted } 1 \mathrm{hr} \\
\text { at } 7000 \mathrm{c}\end{array}$ \\
\hline Nean ooumts per mino & 9221 & 3602 & 3568 & 3 mo & 3348 \\
\hline$\sigma_{\theta} 1$ sample, cpm & 618 & 192 & 175 & 168 & 297 \\
\hline 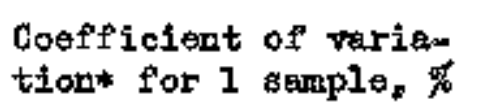 & 6.7 & 5.3 & 4.9 & 4.5 & 8.9 \\
\hline $\begin{array}{l}\text { Coeffiofont of rarien } \\
\text { tion* for } 3 \text { samples, }\end{array}$ & 3.8 & 3.1 & 2.8 & 2.6 & $5_{0} \mathbf{I}$ \\
\hline 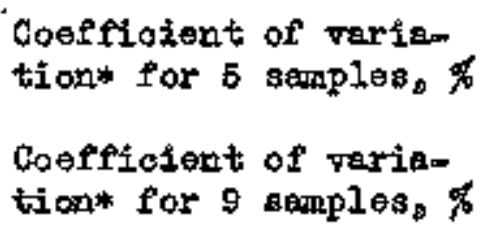 & 3.2 & $\begin{array}{l}2.4 \\
1.8\end{array}$ & 1.6 & 1.5 & 3.0 \\
\hline
\end{tabular}

* $100 \times$ standard deviation/mean

STAMDARD deviations and is probably just signfficanta

A further series of masurements mas made in whioh twenty samples of duat of 0,3 milliliters each were pipetted into orucibles, and entire rat lungs

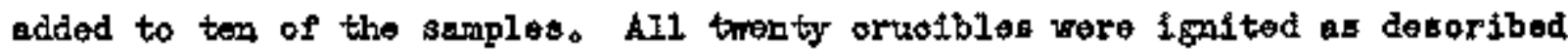
abore and oouted. The results are show in Table 2 (Fug 48 )。

The coefficient of varfation of these samples is comparable to thet of the preceeding series. Again there is a difference between the means which is just signifiognt for groups of ter samples, In order to amalyze this aitustion further, additional kamples were prepared until a total of trienty activity-plogthissue samples vere available covering a range of 0.00 to 2.50 grass of tistue。 The coefficient of correlation between reoovery and tissue weight was cosputed 
48 .

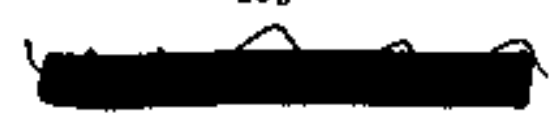

TABLE 2

RECOVERY OF ACTIVITY IN THE PRTSEHCE OF RAT LING

TISSUE, $\mathrm{N}$ = IO SAMPLES BACE.

\begin{tabular}{|c|c|c|}
\hline & $\begin{array}{c}\text { Cracibles } \\
\text { Only }\end{array}$ & $\begin{array}{l}\text { Crucibles } \\
\text { Plus Lung }\end{array}$ \\
\hline 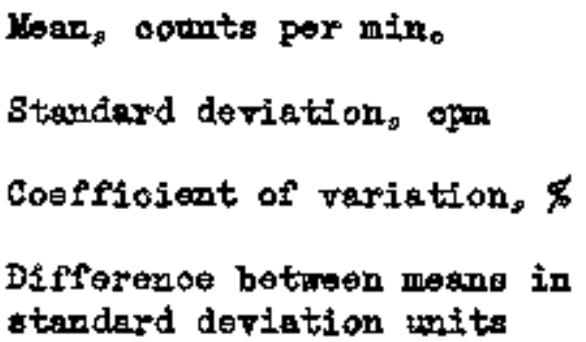 & $\begin{array}{l}886 \\
61 \\
7.0\end{array}$ & $\begin{array}{l}796 \\
71 \\
8.9\end{array}$ \\
\hline
\end{tabular}

- and found to bes

$$
5 \pm 0,16,(3 \pm 20)
$$

This implies that $15 \%$ of the variance is due to the effect of the added tiasue, hence the vartianoe not so accọnted for 1s:

$$
\begin{aligned}
& (\pi)^{2}(1.00-0.15) \\
= & (\pi)^{2}(0.85) \\
= & 4280
\end{aligned}
$$

If the effect of the tissue mere sompletely eliminated the standard deviation would be

$$
\sigma=\sqrt{\text { pariance }}=\sqrt{4280}=65
$$

Therefore we may conclude that the offect of added fisaue on the soltter 18 negligible。

Finsily, a series of meesurements ware ngde on the lungs, Ifrers and kidneys of control rots to deterinine the normal radioactifity ontent as menoured by this teohniqued The reatits are shom in rable 3 (Page 49)。 
49 .

TABIS

RADIOACTIVITY IN LTNGS, LIVERS ARD RIDNEYS OF

CONTROL RATS

\begin{tabular}{|c|c|c|c|}
\hline Organ & $\begin{array}{l}\text { Ho of } \\
\text { Samplea }\end{array}$ & $\begin{array}{l}\text { Net Counts } \\
\text { Per Minate }\end{array}$ & $\begin{array}{c}\% \text { of } \\
\text { Baokgrourd }\end{array}$ \\
\hline Irangs & 10 & $I_{0} 2$ & 6 \\
\hline Liver & 10 & 201 & 10 \\
\hline Kidney & 12 & 108 & $\theta$ \\
\hline
\end{tabular}

Aftex the cruoibles have been ocmited they are treated acoording to the folloning schodula, Bach ocntaminated ortoiblo is rinsed with water and dropped into a bath of bolling $10 \%$ soditu earbonate solution for ons bowr. At the end of this time the orucible ill ringed and pleosd in a bath of warm 6 II AC, where it remains orernighto The following dey it is boiled in the sane bath for $2-8$ hours, changing the bath if it becones bady stained, Finelly, the oruoiblea are rinsed with hot water, poltahed and dried. This procedure will reduce the activity in most erucibles to lose ther 50 counts per minute, of which sbout 25 counts per minute arise from oontamination originaliy present in the poroelain. It is a curious fact that neither solvent bath alone, nor both together in the reverse order, will woogipliah an adequato deocntamination。 Then used as described the procesa leads to the Pollowing results.

$\begin{array}{lr}\text { Het mean count, original oruoibles } & 24 \\ \text { Het mean count before decontamination } & 3343 \\ \text { Het mean count after decontemization } & 51 \text { opts } \\ \text { Baokground } & 23 \text { oprs }\end{array}$

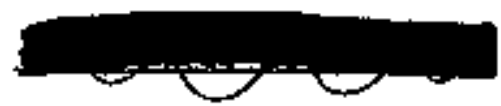


50.

Conolustons. A method is areilable by which the radiogotivity from diverse souroes present in a sof't tiseue may be measured with a prectalon of 6-8\%。 Racorery is slightly 10w, being about 90-92\% on the atrarage, but 1s probably es high ar higher then could be obtained by other wathods, beceuse the mothod deecribed here is largely fndependent of the chemioal propertien of the radiagctive speoies which may be present,

$A$ procedure is described by which the cruotbles used may be decontarinated. 


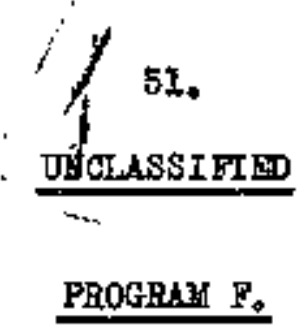

FLIORIDE

Problem Codes $F_{0} 4$ (Fate)

Section Code: 3210

Authors: $F_{0} A_{0}$ Smith, Do $E_{\phi}$ Gardiner, Jo DeVoldre, Ro E, Root, and D, Wing

Blood Mluoride Lepols Following Broosure to Hydrogen Fluoride.

Provious studies on doge axposed to hydroges finoride (UR-70) have

indicated a oomsiderable rariation anong maximal blood fluoride ooncentratione

attaized under conparable conditions of exposure; 11 to 53-fold inareaser

above normal were noted, with noximal fluoride comeontrations of $140.630 \mathrm{ps}$

P/100 mi occurring on the 4-7 exposure degs, Besenge of this somsinat wido

variation, it was considered desirable to ourry out a third exposure study in

order to accuralete additiomal deta relative to the rarietions to be expected

mong different dogs. Aosordingly, two dogs were oxposed for fire ocnseoutive

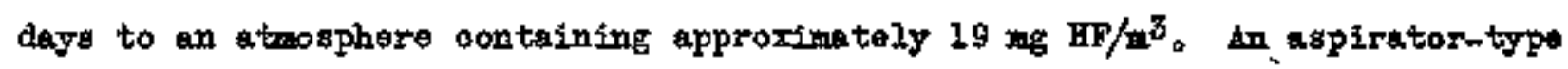

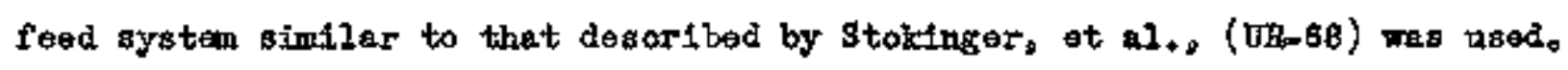

Elood fluoride determinstions were made at regular intervals throughout the

expasuce period, end for 59 days thereafter. The data resulting wro shorn in Table 2 (Page 62).

It it again oridemt that maxtmal blood concentrations are reahad only after exposure has continued for at Ieast two days, It ia apparent liso that these peak levels are of the same order of magnitude ag were emcountered in prevsoul exposures, being 18-27 times greeter than the mean pre-exposure cors. centrations, Similariys the post-exposure data are oomparable to those obtained fn the preceding ten-day exposaxe study; a minjmum 60-day post-exposure interra1 


\section{UTCLASSIFIFI}

Ia necessary before the blood-fluoride concentrations ere restored to preexposure levels, It is interesting to note that en interval of this magnitude is required in splte of the fect that the exposure perfod was only half as great at in the lo-day study.

TABTE

FUORIDE COHTHIT OF BLOOD OF DOAS FRPOSWD TO HYDROGKIT FUORTDE 19 ag $\mathrm{HP} / \mathrm{m}^{3}$

\begin{tabular}{|c|c|c|}
\hline \multirow[b]{2}{*}{ Time Interval, Days } & \multicolumn{2}{|c|}{ Kicrogram $F$ per 100 mal Blood } \\
\hline & Dog Fo. 1517 & Dot Ho. 1.534 \\
\hline $\begin{array}{c}\text { Pre-Bxponure Period } \\
-6 \\
-4 \\
\text { Foposure Period } \\
+1 \\
2 \\
3 \\
4 \\
5 \\
\\
\text { Postrospostro Period } \\
1 \\
2 \\
3 \\
4 \\
5 \\
7 \\
10 \\
12 \\
14 \\
38 \\
25 \\
32 \\
40 \\
47 \\
59\end{array}$ & 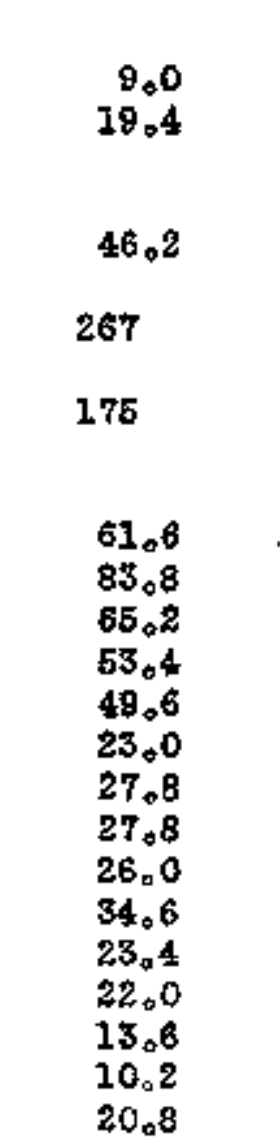 & 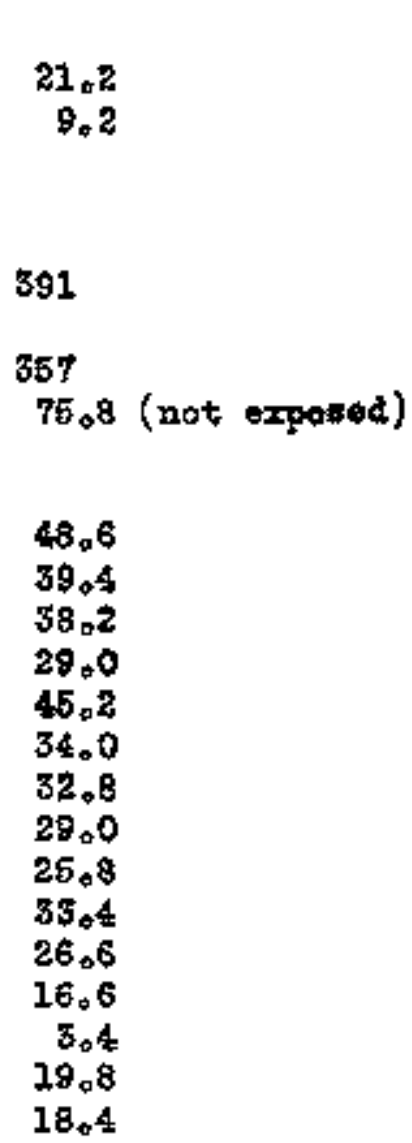 \\
\hline
\end{tabular}


Problem Codes Fo4 (Fato)

Section Gode: 3210

Authors: $P_{0}$ Ao Sinith and Do Is Gardner,

Buoride Lovela in Blood and Jrine of Industrial Personnel.

Continuing investigations into the torioalogy of fluorides have now been extenced to include a study of the eoncentrations of fluoride in the blood und urine of personnel engsged in the industrial production of fluoride compoumds. lihrough the courtezy of Dr. Elmer R. Swanson of the Harshar Chemioal Co. cleweland, there bere obtained twelve spot blood and urine specinens from workers in that compary's fluoride plants, together with an squal nuaber of samples from office and laboratory personnel with none or negligible exposure to fluorides. The ooncentrations of fluoride found in these samples are indionted in Table 1 (Pege 54)。 The mean ooncentration of blood fluoride in the control group was found to be $11.5 \mathrm{pg} \mathrm{F} / \mathrm{h} 00 \mathrm{ml}$, with a standard deriation of $404_{g}$ whereas the corresponding retus for the exposed porsonmel wes 30.4 pg

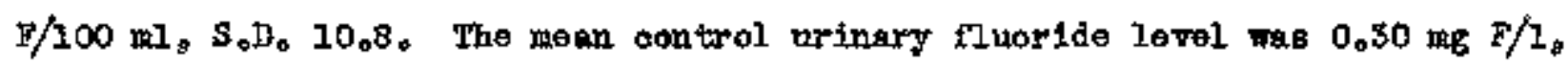
$S_{0} D_{0} 0.18$ mile that for the exposed groups was $1 l_{0} 3 \mathrm{mg} F / I_{0} S_{0} D_{0} 6.2$.

The mean urinery fluoride level of 0,30 ing $F / 1$ for the control group is In regsonable agrement with the value of 0.38 mo $P / 1$ predicted from the date of HoClure and Kinger ( $U_{0} S_{D}$ Pub。 Health Repto, 50, 1575, 1944) for a ooncentration of $0.1 \mathrm{~ms} F / 1$ in the combunity water supply. The mean ooncentration for four sacaples of clevelend water was malyzed as $0.1 \mathrm{mg} / \mathrm{h}_{\text {o }}$

The blood fluoride conoentrations for the oontrol group are in generel gcanewhat higher than have been encountered in control dete colleoted in this ocminuitys in only four instanees, however are they greater than the maximel

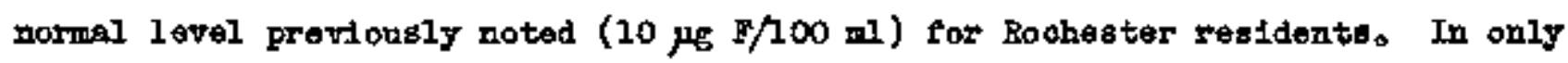
JICLASSIFTED 
TABTE 1

BLUORDD CONTEET OF BLOOD AHD GRTES OF CERTAIN PERSONNEL OF HARSHAT CHEAICAT COMPAFY, CLEVIEAAND, OHIO

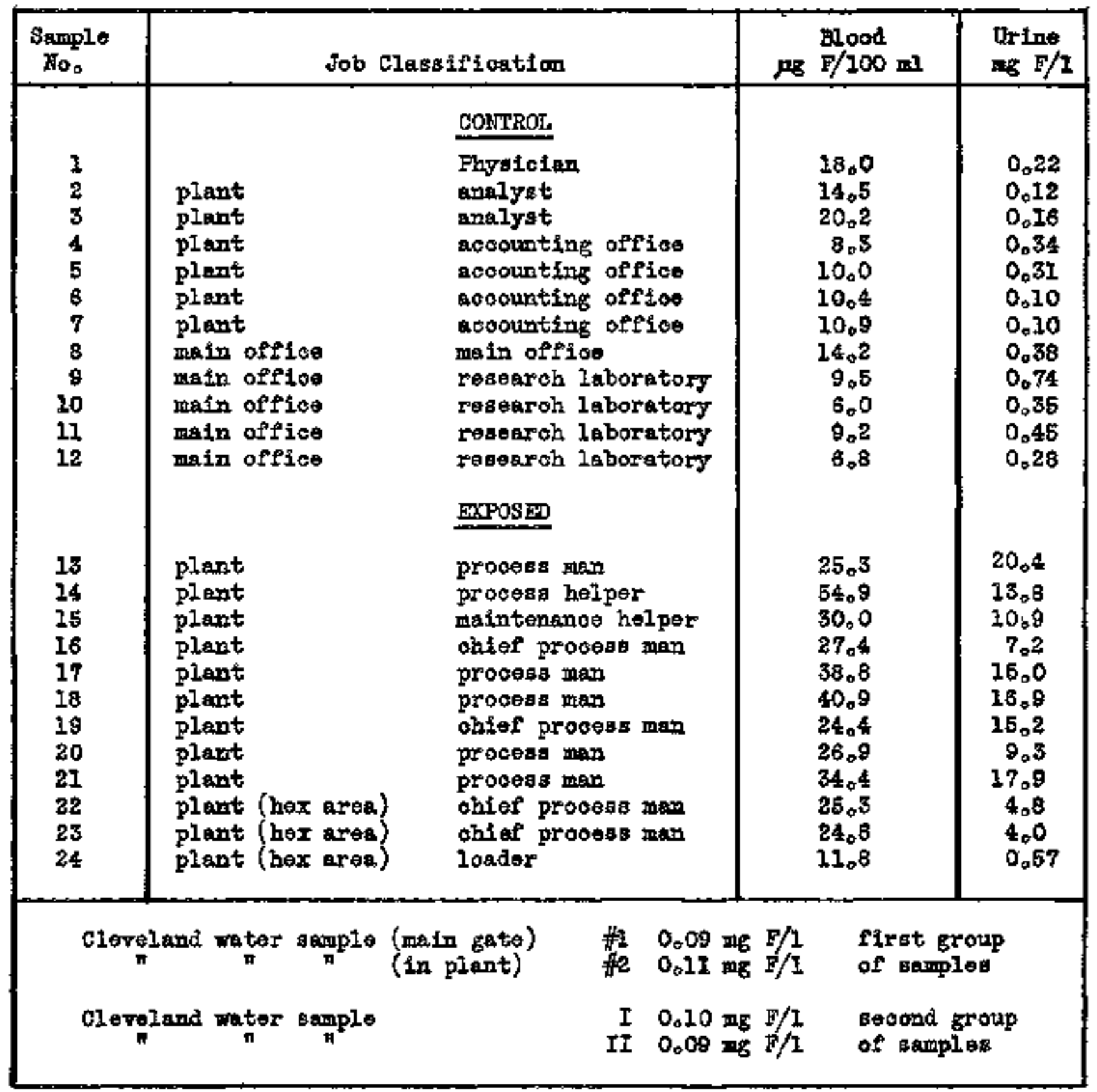

one fintanoe was the blood fluoride ontent of an exposed iadividial within tho range $(6.0=20.2 \mu g F / 100 \mathrm{ml})$ noted for the control group. 
It is evident that there are signiffeant differenos between the neans for the fluoride eontents of the bloods and urings of the two groups of Harsher personnel. The incressed concentretions found for the exposed groupe may be attributed to the greater ooncentration of fluorides present in the plant atwogpheref in intioh thase men work。

Problem Coder Fa4 (Fate)

Seotion Gode: 3210

Autiore: Fo A Smith $\mathrm{H}_{0} \mathrm{E}_{0}$ Stokinger, $\mathrm{L}_{0} \mathrm{~T}_{0}$ Steadman and $\mathrm{D}_{0} \mathrm{~B}_{0}$ Gardiner Deposition or Fluortde and Beryllium In Anjmel Massues Following Erposure to $2 \mathrm{mg} \mathrm{BeF} / \mathrm{m}^{\mathrm{3}}$

Analyzes for flcortde and beryllitw contents have now been aompleted in cerotain tissues of animals exposed to 2 arg $\mathrm{BeF} / \mathrm{m}^{3}$ (mlst) for intervals ranging from 422 to 954 exposure hours, Beryllitun and sluoride in blood were detexmined serially in each of four dogs during the course of the exposures and fluoride determinations have been completed for the epiphysis, kldneg, lum and 11 rer at ternination of the exposure (854 expoatre hours). Similar determinations were carried out on skeletel and soft tissues of the cat after 422 hours of exposure. Fuoride determinations also have been completed on skeletal snd soft tissues of rabbits taken et intervals up to 2.5 months after oessation of 422 exposurt bours. A discusgion of the results obtained follows. Descriptions of the exposure methods, together with the mortality, hematologic and biochemion finding have been reported previously (of, $\mathrm{R}_{0} \mathrm{H}_{\circ}$ fisll, ot al o, URe116)。 In Table 1 (Fage 56) aro listed the fluoride and beryllium contents found for serial blood samples of four dogs during the exposure intervel 


\section{TABLE 1}

FLUORIDE AHD BEEYLITN COFTENT OF BLOOD OF DOGS FXPOSE TO 2 mg BEF/

\begin{tabular}{|c|c|c|c|c|c|c|c|c|}
\hline \multirow[b]{2}{*}{$\begin{array}{l}\text { Exposure } \\
\text { Hour: }\end{array}$} & \multicolumn{2}{|c|}{ Dog 437} & \multicolumn{2}{|c|}{ Dog 1518} & \multicolumn{2}{|c|}{ Dog 1537} & \multicolumn{2}{|c|}{ Dog 71688} \\
\hline & $\begin{array}{l}10 \mathrm{~g} / \mathrm{I} \\
100 \mathrm{I}\end{array}$ & $\begin{array}{l}\text { pg Be/ } \\
100 \mathrm{ml}\end{array}$ & $\begin{array}{l}\mathrm{Ag} F / \\
100 \mathrm{~m}\end{array}$ & $10 \mathrm{Be} /$ & $\mu \frac{F}{100} \mathrm{mI}$ & $\begin{array}{l}56 \mathrm{~B} / \mathrm{m} / \\
100 \mathrm{l}\end{array}$ & $\begin{array}{l}\mathrm{pg} F / \\
100 \mathrm{~m}]\end{array}$ & $\begin{array}{l}\text { F⿱ } \mathrm{Be} / \\
100 \mathrm{ml}\end{array}$ \\
\hline $\begin{array}{l}368.1 \\
398.1 \\
458.1 \\
512_{01} \\
614.1 \\
668.1 \\
704.1 \\
722.1 \\
848.1\end{array}$ & $\begin{array}{r}26.4 \\
8.1 \\
21.1 \\
1.1 \\
23.6 \\
16.9 \\
16.0 \\
18.3 \\
22.5\end{array}$ & $\begin{array}{c}- \\
2.2 \\
2.0 \\
8.3 \\
3.0 \\
4.4 \\
6.4 \\
4.0\end{array}$ & $\begin{array}{l}37.2 \\
23.8 \\
14.4 \\
10.4 \\
20.9 \\
17.8 \\
11.7 \\
20.4 \\
26.3\end{array}$ & $\begin{array}{c}= \\
\overline{2.7} \\
-\overline{6} 5 \\
3.5 \\
4.2 \\
8.5 \\
4.5\end{array}$ & $\begin{array}{r}22.4 \\
15.2 \\
16.9 \\
6.5 \\
19.0 \\
15_{0} 0 \\
10_{0} 0 \\
12_{0} 7 \\
22.6\end{array}$ & $\begin{array}{r}= \\
= \\
3.8 \\
= \\
14.0 \\
3.2 \\
4.5 \\
5.3 \\
3.1\end{array}$ & $\begin{array}{l}42.7 \\
17.8 \\
15.1 \\
20.6 \\
15.3 \\
14.2 \\
22.8 \\
17.8 \\
20.6\end{array}$ & $\begin{array}{r}- \\
- \\
7.3 \\
13.0 \\
4.5 \\
5.1 \\
5.5 \\
4.8\end{array}$ \\
\hline
\end{tabular}

207 calendar days of exposure

$368-848$ expogure hours.

It is erident that there it no progressive tncrease in either fluoride or beryllfum oontent with continuing exposure. Bedeuse pre-exposure blood fluoride determinationg were not made on these dogs, ft is not posajble to stete to whet extent theae latter values are Inoreased over the normal Ievela, How vor, during the past three years, 98 blood fluoride determinations heve been gade on normal dogs. These levels have ranged between 0 and 35 fos $5 / 100$ mil blood, wth a mean level of $6 \mathrm{pQ} / 100 \mathrm{mI}_{\$}$ moreover, only $5 \mathrm{per}$ cent of the veIues have been greater titan $20 \mathrm{\mu g} / 100 \mathrm{ml}$ and 72 per cent have been 10 or less $\mathrm{\mu g} / 100 \mathrm{ml}$. toing these control data, it is apparent that axposure to 2 Is $\mathrm{BeF} / \mathrm{m}^{3}$ probsbly has elewtad the blood fluoride levels of these dogs to some extemt. Horrever, only 2 of the total of 36 deterninations are greater than the higher normal levels. Were the berylifum funoride inhaled by these dogs to be trangported as the nondissociated compond, it would be expected that the quantitien or beryllium and fluoride would be present (on a waight basis) in the ratlo of 
1:4. For dog 1437, it will be noted thet the atergge weight ratio of berylliem to Muoride 1. 1:4.8, while for $\operatorname{dog} 1518$, the ratio is $14_{0} 2$. The agreenent With the theoretioal ratio is not quite so exceliont for dogs 1537 and 1538 where the ratios are $1,3,4$ and $1 \$ 2.9$, respectively, The averege ratio for the entire group of enalyses is epproxinately 183.9 . It will bo noted that this computation is based on, the totel fluoride present, i. $0_{0}$, that fluoride present as a result of the exposure to $\mathrm{B}_{9} \mathrm{~F}_{Z^{0}}$ together with that normally present from the dietary intelce. Thus the actual ratio may not be as high as the oalculated Falue indicates. These data suggest the possibility that the beryllium Fluorido inhaled by these dog may be transported in the blood in part we the nondissoc1nted conagound.

Table 2 belon lists the fluoride contents found for the femoral opiphysis and kidney, ling and liver of these four dogs at sacrifice. Only one control

\section{TABLSE 2}

THRLLALAL FLUORIDE CONTENT OF TISSURS OF DOGS EXPOSHA

TO $2 \mathrm{mg} \mathrm{BeF} / \mathrm{sm}^{3}$

\begin{tabular}{|c|c|c|c|c|}
\hline \multirow[b]{2}{*}{ Dog $\mathrm{Bo}_{0}$} & \multicolumn{4}{|c|}{ FLUORIDE CONTEIN IN PABSS PER MLILIIOH } \\
\hline & Bpiphpsis & K1duey & Lung & LAtrer \\
\hline 1437 & 4190 & 1.08 & 2,3 & 0.5 \\
\hline 1518 & 22BO & 200 & 2.3 & 1.5 \\
\hline 1537 & 2470 & 1.6 & 4.0 & 1.0 \\
\hline 1538 & 2380 & $I_{0} 8$ & 2.1 & 1.0 \\
\hline \multicolumn{2}{|c|}{$\begin{array}{l}207 \text { oslemiar deye } \\
142 \text { exposure days } \\
\text { 854 i expobure hour }\end{array}$} & \multicolumn{3}{|c|}{ 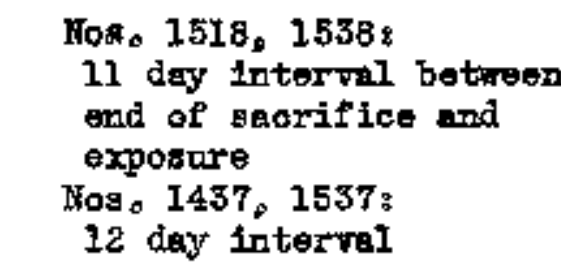 } \\
\hline
\end{tabular}


femoral epiphysis, and no boft tistues from control dogg are arailable for comparison。 A single analyeis of a control optphysis showed 1930 pron $\mathrm{F}$ (ash); dogs 1518,1537 and 1538 are slightly higher in fluoride oontent; rhether or not this is significent carinot be gaid in the absenoe of duta relatire to the rariation to be expected among comtrol dogs. Dog 1437 probably has a sigmiflantly Ereater fluoride cortent in the epiphysts。

The fluoride contents found for the kidney, lung and Ifver of the doge do not differ significantly from those foud for the exposed cats and rabbits (Tables 3 and 4, Pages 59 and 60). Horeover, all of these levels agree ressonably woll Wth noranl values for liver and kldney of the oow grinea pig and oalf as reported by YoClure (Public Health Reptsos $64_{g} 1061_{3} 1949$ )。

Fivoride and beryllium contents of hard and saft tissues of oats at saorifice are show in Table $3_{3}$ compatable fluoride date for one normal cat are also Included here, The fluoride contents of the saft tilaves of the treated cats do not differ signifioantly from those of the one controt cet. The fenur of the exposed antmals, honrever, show a definite fnorease in stored flnoride, as might be expected the average-1norease is approximetely twa-fold over the one control femur evailable. Ho stgificant differences are noted among the fluoride contents of the soft tisster of the oontrol and experimental anirals. It maty be shown that there is no molar relation of fluoride to beryllium in the ling, femur, liver and kidney.

The fluoride contents of hard and soft tissues of rabbits actifioed serially after termination of the exposure are given in Table 4 (Fage 60). The fluoride oontents of the diaphyses do not ohange significkntiy with fnoreagiag post-exposure time. Because of the great variations noted betweed the epiphysis of the two rabbits at each postmexposure interval, no clear-out downard trend TCLASSIFIED 
TABLE 3

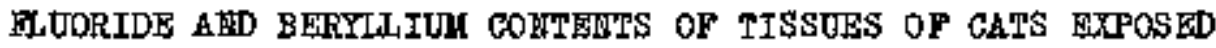
TO 2 mg $\mathrm{BeF}_{2} / \mathrm{m}^{8}(\mathrm{a})$

\begin{tabular}{|c|c|c|c|c|c|c|c|c|c|c|c|}
\hline \multirow{2}{*}{$\begin{array}{l}\text { Ho, and } \\
\text { Body lift. }\end{array}$} & \multicolumn{2}{|c|}{$\infty 013.6$ 理 } & \multicolumn{2}{|c|}{$0025.3 \mathrm{~kg}$} & \multicolumn{2}{|c|}{$604.2 .9 \mathrm{~kg}$} & \multicolumn{2}{|c|}{$12043.0 \mathrm{~kg}$} & \multicolumn{2}{|c|}{$1426 \quad 2,6 \mathrm{~kg}$} & \multirow[b]{2}{*}{ Mormal } \\
\hline & $\mathrm{Be}$ & F & Be. & $\mathbf{F}$ & Be & $\mathbf{F}$ & Be & $F$ & Bo & $\mathbf{F}$ & \\
\hline $\begin{array}{l}\text { Ling } \\
\text { Femur } \\
\text { Ldrer } \\
\text { Biduey }\end{array}$ & $\begin{array}{l}7.1 \\
1.2 \\
0.66 \\
0.05\end{array}$ & $\begin{array}{c}10.9 \\
950 \\
0.3 \\
1.2\end{array}$ & $\begin{array}{l}5.1 \\
2.84 \\
1.88 \\
0.02\end{array}$ & $\begin{array}{c}1.4 \\
840 \\
0.3 \\
0.7\end{array}$ & $\begin{array}{l}5.3 \\
2.2 \\
0.45 \\
0.04\end{array}$ & $\begin{array}{c}1.3 \\
920 \\
0.8 \\
2.6\end{array}$ & $\begin{array}{c}17.6 \\
2.2 \\
0.65 \\
0.04\end{array}$ & $\begin{array}{r}0.9 \\
1170 \\
0.6 \\
0.7\end{array}$ & $\begin{array}{l}5.8 \\
2.2 \\
0.57 \\
0.05\end{array}$ & $\begin{array}{c}0.5 \\
1380 \\
0.7 \\
2.0\end{array}$ & $\begin{array}{c}0.9 \\
560 \\
0.5 \\
1.2\end{array}$ \\
\hline
\end{tabular}

\begin{tabular}{|c|c|c|c|c|c|}
\hline & \multicolumn{2}{|c|}{ BLFTLLIDI } & \multicolumn{2}{|c|}{ FUORIDE } & \multirow{2}{*}{$\begin{array}{c}\text { Cajo: F from } \\
\text { Mean Be }\end{array}$} \\
\hline & Wean & kenge & Hoan & Bange & \\
\hline 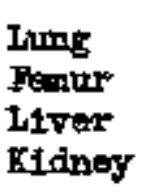 & $\begin{array}{l}8.4 \\
2.1 \\
0.8 \\
0.04\end{array}$ & $\begin{array}{l}5.1-17.6 \\
1.2-2.6 \\
0.45-1.8 \\
0.02-0.05\end{array}$ & $\begin{array}{c}3 \\
110 \\
0.5 \\
1.4\end{array}$ & $\begin{array}{l}5-11 \\
56-164 b \\
0.5-0.8 \\
0.7-2.6\end{array}$ & $\begin{array}{l}36 \\
8.9 \\
3.4 \\
0.17\end{array}$ \\
\hline
\end{tabular}

(a) Be exprosaed as pg/s fresh tisaues $F$ expressed as $\mu \mathrm{g} / \mathrm{g}$ freah soft tissue $\mu \mathrm{g} / \mathrm{g}$ adh femur

(b) Freess from norwal on wet wight basis

is epparent during the postaexposure period umder stady, Also, no control date are arailsble for these tissues in this speoies.

The soft tissues shor no signiflcent differenoes, elther anong thengelves

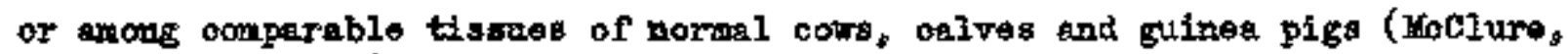
$\left.100.0 I t_{0}\right)$.

\section{Conclustions.}

1. Bxposure of $\operatorname{dog}_{3}$ for $B 48$ hours to $B e P_{2}$ at a poneentratson of $2 \mathrm{mg} / \mathrm{m}^{3}$ produces a slight increase in clroulating blood fluoride. Sanall quantities of beryllimm are also encountered in this tissue. Wo progressive inarease is noted, hotrever, for either fluoride or beryllitm with inoreansng expasure。 
$60_{0}$

DICLASSIFLED

$\therefore:$

TABLF 4

FHORIDE COYTENT OF TISSUES OF EABBIFS BXPOSBD TO 2 mg $\mathrm{BeF} / \mathrm{m}^{3}$

\begin{tabular}{|c|c|c|c|c|c|c|}
\hline \multirow{2}{*}{$\begin{array}{l}\text { Rabbit } \\
\text { ro. }\end{array}$} & \multirow{2}{*}{$\begin{array}{l}\text { Post-Axpoarare } \\
\text { Interval }\end{array}$} & \multicolumn{5}{|c|}{ KLOORIDE COWTEHI IX PABRS PER MILLION } \\
\hline & & Epiph & Diaph & Kidney & Lung & Liver \\
\hline $\begin{array}{l}300 \\
354\end{array}$ & Terminel & $\begin{array}{l}3900 \\
5470\end{array}$ & $\begin{array}{l}2900 \\
3910\end{array}$ & - & $\begin{array}{l}1.9 \\
1.4\end{array}$ & $=$ \\
\hline $\begin{array}{l}353 \\
352\end{array}$ & 3 meeks & $\begin{array}{l}4900 \\
4080\end{array}$ & $\begin{array}{l}3050 \\
2780\end{array}$ & $\begin{array}{l}1.7 \\
5.2\end{array}$ & $\begin{array}{l}1.0 \\
1.9\end{array}$ & $\begin{array}{l}0.9 \\
0.8\end{array}$ \\
\hline $\begin{array}{l}351 \\
350\end{array}$ & $1.5 \mathrm{mos}$ & $\begin{array}{l}3710 \\
3630\end{array}$ & $\begin{array}{l}3420 \\
2890\end{array}$ & $\begin{array}{l}2.3 \\
1.6\end{array}$ & $\begin{array}{l}1_{0} 7 \\
1.2\end{array}$ & $\begin{array}{l}1.9 \\
1.8\end{array}$ \\
\hline 349 & 2.5 mod. & 3870 & 2830 & 102 & 1.5 & 0.6 \\
\hline
\end{tabular}

102 eslendar dag*
70 exposure deys
422 oxposure houra

Hos. 300, 35484 dey intarral between end of exposure and sarifies

2. The data uggest that inheled $\mathrm{BeF}_{2}$ nay bo transported in part in the blood in the molar ratio rasembling that of the subaled ompound.

3. No stgnificant changes from the normal are noted in the fluartide

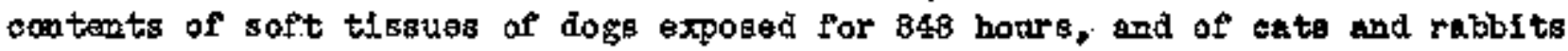
exposed 422 houra to 2 mg $B P_{2} / m^{3}$. Beryllium is foumd in the tissues of these animal 8, but no molar relationships can be demongtrated for the two elomenta 5in these tissues.

4. Inoreased depostition of fluoride ia noted in the skeletel tiasue of the dog and eat, and probably of the rabblto jhowever. there are insuffectent dete for control anfmals to permit an estimation of the nagaltude of this inorease.

5. The difflevlty of interpreting these deta quantitatively indiester the noed for more ench analysea of tisaues of oontrol or nonexposed antmals 


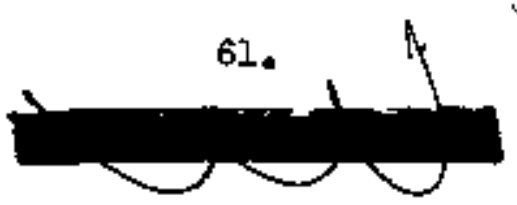

PROGRAM Zr.

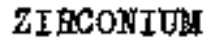

Problem Code: 2r.3 (Tarto Limits)

Section Code: 3230

Authors: C. J. Spiegl, S. Waskin, and M. Calkins,

Current Status of Industrial and Experinental Zixoonim Foxtoity.

Stmmary of Findings from Spot Industrlal Surveys of two Zirconium Plants.

The cumrent interest in giroonium and $i t s$ compounds and the lack of Ifterature on

the toxicity of these materials has prompted further toxicologle invertigations.

Reoent papers by Drabois (Arch. Ind, Hyg, end Oecup. Hed,., 1, 637, 1950) wnd

- by Schubert (Soience, 105, 389, 1947) (J. Ieb, \& Clin. Hed., 34, 313, 1949)

conflim previous reporta as to the low order of acuts toxicity of zirconitum

compounds administered orally or intraperitoneally.

$=$

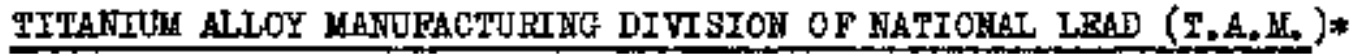

In brief, the manufaturing prooesees employed at T.A.W. are the following:

Io Ore cleanlng - Crude Florida or Australian Ti-zr sand is freed of

ordinary $\mathrm{SiO}_{2}$ and at the mine.

II. Ore Separation - Electromagnetic-static separation is used for separation of ilmenite, rutile and ziroon. Jypieal zircon (eirocuiun sillcete) producta arę:

A. Cruide

1. Alrconite sand " A $^{n}$

2. Ziroonite flour

* The T.A.He plant in Higgra Falze was visited by Drs. Stokfoger, Spieg1, lessrs. DeVoldre and Calkins for the purpose of observing the manafecture of aircontur compounds, Nr. R. A. Easton, Flant Hanager, and Dr. Urban, Research Director, gave the group a background of the ohemical and medical aspeots of zirconsun and arranged a domprohenelve inspection of the produation areas.

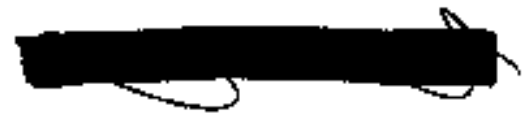




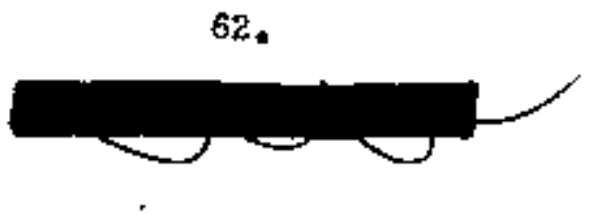

B. Refined

1. "G" zircons

2. TAM ZI roons

3. Ifropgex and superpax (smill pertide-size produots)

14ixgd producte of ziroon are also made. These are combinstions with oxides of barium, caloium, magnesium or zino trmbled together in a dry ball mill. Typjeal product - beriur zirconium silioate.

III. Production of Zircontum Oride fram Zireon

A. Weighed amouts of gircon and coke are interaititently shoveled by hand during a $36-40$ hour period into an open graphite-elactrode orucible furnace until the furmece becogies full. This is a prooese erolving immenge heat and copious quantities of suoke and fumes. The chemical reactions taking placo include the conversion of carbon and silicon to their monoxides and burning of the monoxides to the dioxides. The zitoonfun silicete becanes zirconitua cyanonitride (or a mixture of zirconim carbide and nitride).

B. The hot melt is treated in one of two ways:

1. It is covered and ellowed to cool completely and is sent as the oyanonitide to another ompeny for ohlorimation.

2. The melt is allowed to harden but while still red hot is placed on open grateg where air by convection produces oxidation and deerepitation of the ziroontim cyanontaide to crude zirconium oxides.

c. Crude zirconitum oxide is heated in a rotating oil-heated furmace to remove residual carbon.

D. The oxfde is ball-mill ground to various sieve sizes. Typioal producte are opax, treopax and CP zircomiun oxide.

$E_{0}$ The ortde is mixed pith oxides of barium, ealetwa or magnestua.

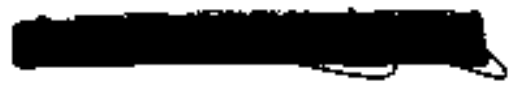




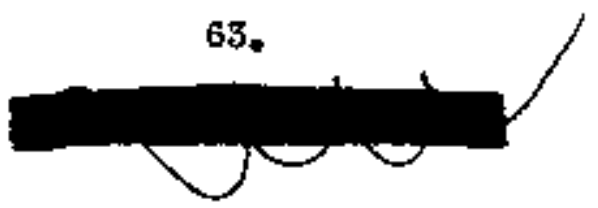

Typioal prodtotitis baritum zirconate (ticon $\mathrm{BZ}$ ).

TV. Ziroonian obemicals are produoed from the zircontum tetraohloride

(Step Bl) by hydralysis of the coupound and addition of the appropriate acid. These are vat processes producing zirconiur sulfate, acetate, hydrate and hydrated carbonatoi.

Typical uses of zircontum compounds are:

1. In enomels and glazes

2. For production of refractories

3. Eleotrical insulators and dieleotrica

4. Support for catalyst

5. Preparation of water repellent compounds for textiles and fura.

6. Possible future use as deodorant, poison ivy ointment end radioopague substance

Flant Samples. The major sites of possible atmospheric oontamination at thia plant were the furnace area and the cyanonitride oxidation room. Conoentretion samples were collacted with a Filter Paper Dust Sampler and those for partiole size with a Casoede Impactor. Sempling rates for both methoda were 14 11ters per minute. Analysis of the bauples was made by the spectrographic method for ziroonium. The filter paper sanples were also analyzed for silicon content. Ten-minute sanples rere taken by each of the methode in the furnace area under conditions that were considered typical. The filter paper dust sanple showed a total of 190 mforograms of atroontim and only 6 fg $(3.1 \%)$ of silfcon. The calcuiated ziroonjim eir ooncentration ralue mas $1.4 \mathrm{mg} / \mathrm{m}^{\mathrm{s}}$. In comparison with this value, the air conoentration lewel determined fram total sample collected with the Cascade Impactor was of the same order of magritude (1.9 mg/m3). The results of the proftcle size malysis showed typiculiy normal alstribution

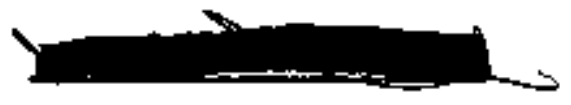




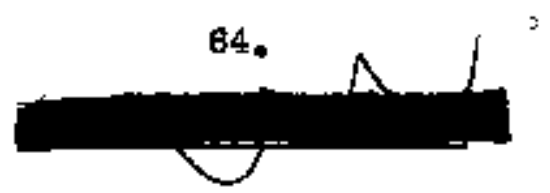

With a mass-median dlameter of $1.51 \mu$, with a parresponding geometric stenderd devitetion of 2,85 ,

The girooniun oymonitride oxdation room was also sampled under typioglly normal conditiong. The concentretion data showed higher valued with $3.6 \mathrm{mg} / \mathrm{m}^{3}$ obtained by filter paper tample and $7.8 \mathrm{IRg} / \mathrm{m}^{3}$ determined fran the total semplo collected with the Gasoade Impaotor. A total of $500 \mathrm{gg}$ of ziroonitum was obtained on the filter paper sample but in this case less than 1 gg or approximately 0,14f silic on was found, Signifieartly larger particlo size was prosent in this ares.

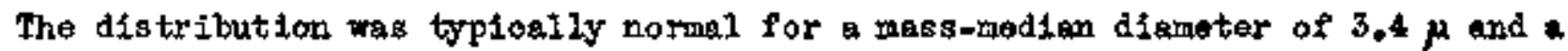
corresponding geonetrio standerd deriation of 2.52.

If the partiole gize date are exaringd in terrs of the sizer rapresenting the physiologically toxic range of less than $1 \mu$ (an essumption bused on our experiezmits relating to the physiologic effects of guall partioles), the vample oolleoted in the frrmace area shored $35 \%$ of the mas oonentration to be present in eizeg below $1 \mu$, wherees the emple collected in the cyanonitride oxidation area shored only $7 \%$ of the mase coneentration to be present belor 1 po Racal outation of the probable effeotire air conoentration, the refore, indicates relues of the ame order of magnitude for both areas, namely, 0.7 and $0.6 \mathrm{mg} / \mathrm{m} 3$, respectively. Four ziroonfug bulk semples were also obtained from the plant and subjeoted to physioal analysis. The partiole sizo and specific surface dati obtained on these semples are shown in Table 1 (Page 65). The samples showed large differenoes in particle size as determinod by optioal mioroscope measurements, tarying fram a mags-median size of $2.39 \mathrm{p}$ for the pure $\mathrm{zxCl4}$ to a value of $9.0 \mathrm{p}$ for the phes dize of the zirconium cyanonitride. Since this latter ralue wes so muoh higher then those of the other samples, the optical microscope nessurement for cyanonitride rae repeated. In this onse ralue of $8.8 \mu$ was obtained for the

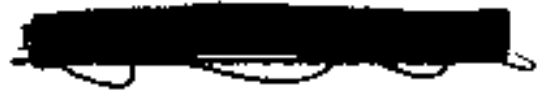


TABH 1

SFBCIFIC SURRACE AND RESATED DATB FOR BULK ZIRCONIUN COUPOOWDS (a)

\begin{tabular}{|c|c|c|c|c|c|c|c|}
\hline \multirow[b]{2}{*}{$\begin{array}{c}\text { Sample } \\
\text { Desoripttion }\end{array}$} & \multicolumn{4}{|c|}{ PAFTICLE SIZE (o) } & \multicolumn{2}{|c|}{ SPECI FIC SURFACE, } & \multirow[b]{2}{*}{ Porosity } \\
\hline & $\begin{array}{l}\text { Mess } \\
\text { ladian, } \mu\end{array}$ & $\begin{array}{l}\text { Geo. Stand, } \\
\text { Devo of } \\
\text { hess lifdian }\end{array}$ & $\begin{array}{l}\text { Count } \\
\text { Hedis, } \boldsymbol{\mu}\end{array}$ & $\begin{array}{c}\text { Surface } \\
\text { Madian, } \mu\end{array}$ & $\begin{array}{l}\text { Gelo. from } \\
\text { Partiolo } \\
\text { Dindeter }\end{array}$ & $\begin{array}{l}\text { Ey Ethane } \\
\text { Adsorption }\end{array}$ & \\
\hline TAMT $\mathrm{zrCl4}, \mathrm{Z}-135$ & 2.4 & 2.1 & 0.38 & 1,4 & 0.29 & (b) & \\
\hline TAN $2 \mathrm{rO}_{2}, \mathrm{O}, \mathrm{P}, 2-185$ & 3.5 & 1.9 & 0.90 & 2.8 & 0.13 & 8.8 & 29 \\
\hline $\begin{array}{l}\text { TAtr Superpax } \\
\mathrm{ZrO}_{2} \mathrm{SiO}_{2} \text { Pines }\end{array}$ & 3,0 & 2.9 & 0.73 & 2,0 & 0.20 & $3_{0} 2$ & 16 \\
\hline $\begin{array}{l}\text { Dust frat } \\
\text { Bag Filter (d) }\end{array}$ & 9.0 & 2,2 & 0.86 & 5.7 & Q.047 & 5,2 & 111 \\
\hline
\end{tabular}

(a) Semples obtained fram Titanium Alloy Yfg. Dira, Nationel Laad Co, Nagara Falls, F. Y.

(b) This sample was found to decompose under the high veculw degessing reguired prior to ethane adsorption.

(c) Walaurements by optical mforoscope based on a count of 1000 pertioles per sample.

(d) Atr frain zireanium cyanonttride burning room, 
mass median size, thus checking the original determination, Electron micrographs of these samples showed no unusuel structure end in general confirmed the particleeize measurements by the optical microsoope.

Specific-surfece determinations by lor-teraperature adeorption of ethane ars reported for all samples except $\mathrm{HrCI}_{4}$. The aurface ralue of this compoimd could not be deterzined by the adsorption nethod because it deconposed under the high vectum degessing trestment which is reguired prior to othane adsorption. The speoific-surfece values of the remaining thros ziroostum oompounde were in close agreement, It might be expected that the surface ralue for the $\mathrm{Zr}_{\mathrm{r}}$ cyenontride asple would be extrenely low due to the large particie sizef however, this serple showed the highest ralue of the three, indeating a relatively high "internsl" surface. Ho evidence of suah struoture, however, could be denonstrated at an increased magnification to $18,500 x$. A porosity value of 111 for thls semple fndicetes an internal aurfase at least 4 times as great as those of the $\mathrm{ZrO}_{2}$ and $\mathrm{z}_{\mathrm{r}_{2}} \circ \mathrm{SAO}_{2}$ gemples wich showed porosities of 29 and 16 , respeotivelyo Hedical Histories Aooording to Dr. Urban, the incidence of 11lness gurong plent rorkers is rather low and does not differ from that of any other typical manufacturing plant in the industry. At present, a progran of yearly roray exconinations is in effeot, Although this program hat not boen in offoot during the entire 30 yeare of plant operation, only 2 otsed of lung darnge, of uproven origin, have been reported during this time, Forking personnel overege: Qpproximately 200 。

Summary and Conclusione。 ìo unusual industrial hazard probl ems there found at this planto Although zireonim concentrations of 1,4 and $3_{p} 6 \mathrm{mg} / \mathrm{m} 3$ were formd by the Fister Paper Dust Sampler uder typioal oonditione, oalculatione showed that these conoentrations represent values of only approximately 0,6 and

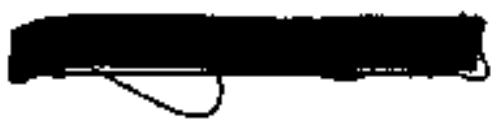




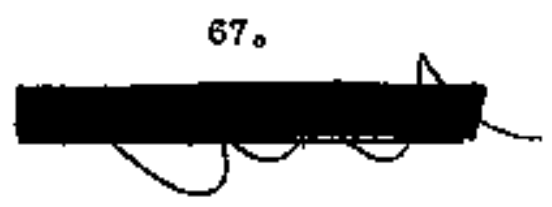

$0.7 \mathrm{mg} / \mathrm{m}^{3}$ of probeble phyiologioally-active inaterial. The low ineidence of industrial disease under these plent conditions does not engget that * nefor, soute toricity problem exists with these compounds, FOOTE MTAERAL COMPANY*

Frooessed employed by this firm are the following:

I. Formation of the POCl $\$$ Complex - Elrconim tetraohloride obtatned either from the local plant or from other sources is placed into a roundbottom, pyrex flask and da allowed to react with liquid Poclyo Exposure to airconitus tetrachloride is mintmized by providing adequate air ventilation and exposure to POCl 3 is esaentially prevented by using a closed syster.

II. Diatiliation - the $\mathrm{ZrCl}_{4} \mathrm{POCl}_{3}$ complex ts diatilled in a large glass oolum at head terapereture of $355-360 \mathrm{C}$. During the 30 -hour period of a ofale rarious frections are oollected and by recycle and re-dietiliation a apecial high-purity. lor tef frection is obtatned.

III. Produotion of $\mathrm{Zr}(\mathrm{OH})_{4}$ - Propyi alcohol $\left(\mathrm{C}_{3} \mathrm{H}_{7} \mathrm{OH}\right)$ is introdtced under $\mathbb{I}_{2}$ presgure into a pyrox flask contatring purifled oomplex at $80 \mathrm{Co}$. Iitrogen pressure forces the liquid into a vat conteinlog hot rater. The addition of $\mathrm{NH}_{4} \mathrm{OA}$, with a stirring, oauses preoipitation of ziroonlum hydroxtde, APter settling, the $2 \mathrm{r}(\mathrm{OH})_{4}$ is washed three or four times with digtilied water and placed into stlice trays.

IV. Formation of $2 \mathrm{rO}_{2}$ - the silica trays ontaining the zircontur hydroxide are placed in a furnaco, having veatilation, to form the oxide, Plant Saples; The major site of pos gible atmospheric onteraination at both the regearch and pilot plant was in the area of the distillation oolumm

* Dr6, Stokinger, Spiegl, Nears. DeVoldre and Calking visited the research laboratory of the Foote Nineral Compeny at Berwyn, $\mathrm{Pa}_{\circ}$, and the merufacturing plant at Pacli. Pa, Br。 $S_{\circ} G_{0}$ Ogburn, Lenager of Research and Dereloprant; and his associate, $\mathrm{Hr}_{\mathrm{s}}$ Fisher, made arrangements for us to discuse the processes and to visit appropriate sempifing sites. 


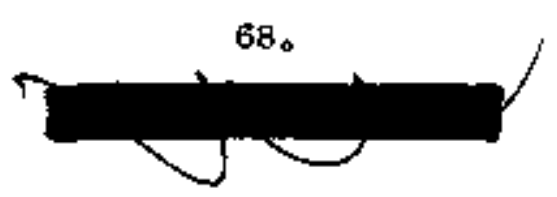

heed. Samples for both coucentration and particle size wore collected with the Cascade Impactor at a sampling rate of 14 liters per minute, The etrospherio contandant appeared to be an ocomsional wisp of clout, indiogting mist or rapor. Although the actual oompound prosent may be a $4 \mathrm{COl}_{4}{ }^{\circ} \mathrm{POCl}_{3}$ camplex, or a hydrolgsts product, the samples were analyzed speotrographleally only for zircontum content. In the laboratory at the still head of a reaeareh-sovie prosess, a sampling time of 65 sinates was needed. An atalospher1s concentration of $0.034 \mathrm{mg} / \mathrm{ms}^{3}$ was determined from the total semple collected, k nomal partlole size distribution

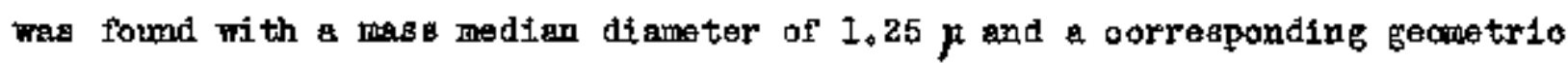
Btandard devition of 2,08 . Thirty-nine per cent of the mas opoentration was found to be below $1 \mu$ particle size, The probable physiologleal effective air concentration mas therefore caloulated $0.013 \mathrm{mg} / \mathrm{m}^{3}$. A corresponding sample was taken at the atill head of the largendiameter glass distiliation colum used in the pilot plant. In this ares, a sompling time of 32 minutes mas used. The air concentration of $0,044 \mathrm{mg} / \mathrm{m}^{3}$ obtained was not considered signt fiotantly higher than that obtained in the researeh area. Particle sises were larger, however, with a mass median diameter of $2.29 \mu$ and a corresponding geometric standard deriation of 2.26 . For this seraple, only I6\% of the mass eoncentration was present in sizes below $1 \mu$, resulting in a probsble physiologioal ly effectivo concentration of $0,007 \mathrm{mg} / \mathrm{He}^{3}$.

In order to provide a saple of momentarliy high concentration tiplfying a still block or blor, a ope-minute sample was taren during a deliberately simulated ondition. For this semple, an atrospherie conoentration of 20,6 $\mathrm{mg} / \mathrm{m}^{3}$ was obteined in the indrediate vicinity of the stil head. Partiole size distribution showed that the inorase in concantration ras aocompenied by the production of larger partfoulates, A mass medien dieneter of $4.30 \mu$ and a

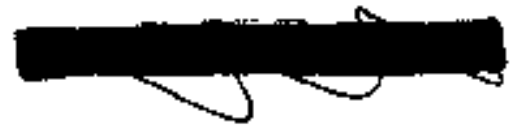




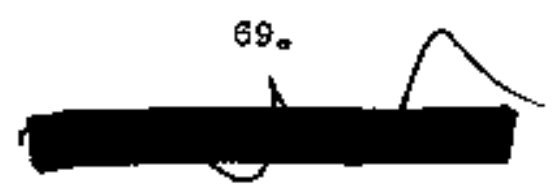

oorresponding geometrio standard deviation of $I_{8} 91$ was obtained. The porcentage of mass comoentration belor $1 \mathrm{p}$ was very low (1\%), reaulting in a physlologically effective ralue caloulated as $0,206 \mathrm{mg} / \mathrm{mi}^{3}$.

Yedioal. The operations are cerried out under adequate ventilation. Ang exposures that may occur result mainly from leaks at joints or eccidental breakngo of apparatus. The prinoiple haxard eppears to 1nclude exposure to $\mathrm{POCl}_{3}$ at the strill hesd; this has oused srinor throat irritation and eylnptores typioal of a common "head cold" that may porsiat for two or three deys. Exposures to zr compounds are limited to the vapor of the complex at the still head, to perlodfo oharging of stili-pot with $\mathrm{ZrCl}_{4}$ and to the mamal heodilng of the insoluble zirconium hydroxide and oxfdes During Deoember, the process was entirely on a pilot plant acale。

Surmany and Conolusions. Because of the nemess of the process and the relatirely smell number of people employed, no adequate sstinate oan be made of the hazards inrolred, Conoentrations in both researoh laboratory and pilot plant aread Indioated extremely low values in the order of $40 \mu \mathrm{p} / \mathrm{m}^{3}$. Suller partiole stzes were indicated in the researob laboratory areas then in the pilot plant (4Rt) $1.25=2.29 \mu)$.

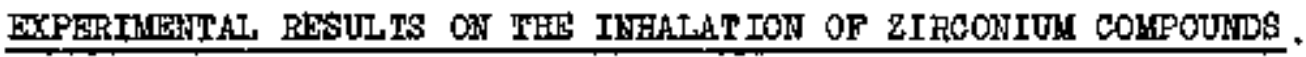

Animel inhalation experimenta with a consentration of afroonim tetraohloride considerably greater $\left(20,5 \mathrm{mg} / \mathrm{m}^{3}\right)$ than that found in tho planta confirms the prelininary estimate of the relatively low aute toxioologio hazerd of $z$ ircontism compounds。

2iroconim tetrachloride was chosen for the intilal 60-day inhalation study beause of its ridespread industrial uEsge, solubility in water and relative ease of analysis by the speatrographic mothod, Time-oonsuming diffioulties with

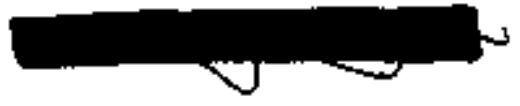


70.

dry dust feeds foreed the use of an serosolizer and a solution of $\mathrm{ZrCl}_{4}$ * Preslamably, this solution contained $\mathrm{zrOG}_{2}$ instead of $\mathrm{ZrCl} 4$, but probably represents an approxination of the beharior of $\mathrm{ZrCl}_{4}$ in efr. The atmogpherio concentration of $\mathrm{zrCl}_{4}$ was maintained at a level of $20 \mathrm{mg} / \mathrm{m}^{3}$ and an arerago mass Isedien diemeter of $0.57 \mathrm{p}$ and standerd deviation of 2.62 .

The operation of the chamber followed establishod Rochegter prooocure. Animgle were exposed for 6 hours on each week-day. During this time, hourly fliter paper dust samples wore meighed as a gulde to athospher ic omcentrations. In additton, one sample dally was andyzed spectrographfoally for the $z r$ content. Weekly Cascade Impactor samples were analyzod spectrographically for the sizodistribution of the gircontum in the chamber air.

A total of 8 dogs, 4 oats, 20 rabbits, 20 guinea pige and 72 rats were exposed. Of these, 4 dogs, 20 rats end 10 rabbits will later also be exposed to $\mathrm{ZrO}_{2}$ in an attempt to utilize the cumplative effeots of aoute exposurea to r sinulate a chronic。

Foekly urinary protein deterninations on 4 dogs and 4 rabits gave only slight, variable results.

Weekly blodd nonprotein nitrogen studies on the gane 4 dags ond 4 rabbits geve inconclutive resilts The dog blood fibrinogen levels similarly were normal,

The 4 doga examined hematologically Bemi-monthly showed progressive decreases in the count of the red blood cells and an inerease in mean corpuscular rolume. haxtral blood ohanges in dogs ware soon at perlods as oarly as 10 days and as late as 52 days after the stert of exposurs; decreases of red coll conats appraximated $1.6 \times 10^{6} \mathrm{cell} / \mathrm{cu}$ Int; hemoglobin decreased about 4 gmp man corpusotiar volune increased 11 to 16 ou $\mu$. One mionth after exposure, blood

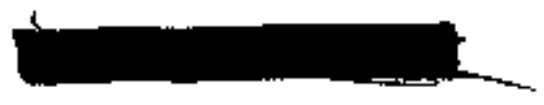


values were within the normal range, Other parlables appeared to change at randon. Woekly weight records showed little except for a transient loss of weight mong the guinea pigi. No histologic pathology in yet availeble on the 44 antmals of 5 speoies gaoriftoed terminally nor on 15 rats sacrificed ofrilly during exposure, Grossly, the only evidences of demage were henorrhage and congolfation of the lung of a fer dying rats and guinee pigg, Hembers of a group of 20 rate are being ageriftoed at interrals up to 48 weeks after exposure to determine tissue repair rate and girconium disappearance rate. The tisgus being studied histologically include o complete autopsy for the dog, cat and rat, Lung lifer and kidney only are being takeb fros the rabbit and guinen piga Analyses for tirconium are being made of the lung, liver and kiduey of all anfmale plua the pulmonary lymph node and femur from dogs, cate und rats. A group of 10 rats and 10 rabbits was handled in manner similar to that of the expoged animals with the exoeption that these received no eirconium serosol. These enfmals serve as a base-Ifne level for control of tulnown fectors Influencing the criteria stadied. 


\section{UNGLASSIFIFa}

\section{PROGRAY I.S.}

\section{ISOTOHAS}

Problem Code: I.S.5 (Therapy)

Section Code: 3310 and 3340

Anthors: H. B. Mason and J. R. Higyes

Approximately nine months ago o ooparative program was instituted whioh would make radio-isotopes available to private physicians in the coumunity. Briefly this plan is for private phraiofans to refer patients for diagnostio studies of therapy to the radiology departuents of the cooperating hospitals. The patient's oase is then reviewed by the Isotope committee of that hospital. and the necessary isotope is requeated in a form autable for aduinistration to the patient. To date, most of the work has bean with $f^{131}$ and the Glinical Chembetry Section, In addition to atandardizing the isotope and preparing it for admintistration, has also carried out the laboratory work necesany for urinary I I3l studies, with the understanding that this portlon of the wort will be taken over by the ooopereting hospltals as soon as conditions perrit. The present brlef raport deals only with the iaboratory part of the program. During the last six months approximately 160 requests for Ii31 hare been filled. and urine studies hove been done in almost sll instances. The usual practioe is to colleot three urine specimens, oorresponding to (2-12 hours, 12-24 hours, and 24-48 hours after administration of the lsotope. The $I^{131}$ content is determined by a procedure involving comparison with $I^{131}$ otenderda. This tochnique ellminates decay oorrections, andily adrantageous in other reopeots.

During the course of the present program, repeat wrinary excretion JWCLASSIPIED 
atudies have been done on a fair number of patients, and on the bests of these cases it is possible to arrive at a tentative estimate of the reliability of urinary Il3i meekuremgnts. The data are frin 26 patients repelving both tracer and therapeutio amounts of $I^{131}$, who showed no clintoal evidence of thyrold Instability orer the period of less than two months between the two studies. These patients all had the tracer dose (usually 50 microcuries) before the therapentio dose (6-20 milliouries), and there was no reason to suspoot incomplete urine collections. The dete are not otherwise selected. The standerd deriation between the two values for the total 48 hour urindry IIII for these pationts is 11\%. Perhaps a more useful form of this figure is that the man urinary Il31 for a given gatient $F 111$ be within $\Psi^{\circ} 20 \%$ of the reported flgure in $90 \%$ of the ogses. An exemple or two will make the application elear. Suppose that $15 \%$ of a tracer dose of $\mathrm{I}^{131}$ is reoovered in the uring oollected during the first 48 hours folloning adminfitration. In the ebsence of oridemes to eliggest incoinglete urine collection, there is a $90 \%$ chance that the mean wrine otitput of $I^{131}$ 11es between $12 \%$ and $16 \%$, and Interpretetion is quite clesr provided the clinioal picture is not strongly egeinst the diagnosis of hyperthyroidism. In another Instance, suppose $40 \%$ of the tracer dose 1 s reoovered in 48 hours. Here there is a $90 \%$ chance that the mesn output lies between $32 \%$ and $49 \%$, and Interpretation rill depend a great derl on the elfntoal plature. As more data sre oolleoted It may be nepessary to modify the above figures, but for the progent they are useful.

In an sttangt to detect the presenoe of possible aberrent or retestatio thyrold tisgue, II3I urinary exoretion studieg have been carried out on a patient during the early postoperative period following total thyroldectory for cercinome. Blghty microcurles of $1^{131}$ wore adrainistered end the patient had DACLASSIFIDD 
an in-dwelling catheter to insure complete solleotion of urine. I I3l $^{\text {B tudies }}$ under such ofrcumstances are relatively uncamon, end the date are reported in full.

\begin{tabular}{|c|c|c|c|}
\hline \multicolumn{2}{|c|}{$\begin{array}{l}\text { Collection } \\
\text { Period }\end{array}$} & \multirow{2}{*}{$\begin{array}{c}\begin{array}{c}\text { Drine } \\
\text { Volume }\end{array} \\
687 \mathrm{ml} .\end{array}$} & \multirow{2}{*}{$\frac{\begin{array}{c}I^{331} \\
\text { Recovered }\end{array}}{39.5 \%}$} \\
\hline $1 \approx t$ & $6 \mathrm{mrs}$ & & \\
\hline and & 6 hrs. & 610 & 27.1 \\
\hline Znd & $12 \mathrm{krs}$ & 386 & $17 \cdot 3$ \\
\hline $3 r d$ & $12 \mathrm{hrs}$. & 588 & 10.0 \\
\hline \multirow[t]{2}{*}{ 4th } & $12 \mathrm{hr} 8$ 。 & 300 & 2.5 \\
\hline & & & $96.4 \%$ \\
\hline
\end{tabular}

The uncertainty in the deteratnations is believed to be in the neighborhood of 10\%, and the results are compatible with complete abaence of active thyrold tisaus.

A laboratory trafning progrem has recently been conduoted for the interested personnel of the oooperating hospitals, and these groups are now 1 gradually taling over the determination of $7^{3} 31$ in wrines. The clinical Chemietry Seotion will sontinue to do the standerdiestions and prepare the I31 for actmiristration to the patients, as well as to oheok the irine determinations from time to time. 
PROGRAM I. W.

ITS TRUMFHTATION (SPECTROSCOPY, ELECIRON MICROSCOPY, I-RAY AMD

BUCL,EAR RADIATIOH DETECTORS, X-RAY DEFFRCTION, H,BCTRONICS )

Problem Code: I.M.I (Researoh and Development)

Section Codes 3110

Author: A, F, Dahl

Quality Braluation of $X-r a y$ Beang by Hetal-wal led Ionization Chanbers.

Beckground. For severd years the writer has been thinking about developjng

a simple, reliable system for quality areluation of a heterogenous bean of x-rays, The systems of heIf-ralue-layer, effective wavelength, and effective energy at best give information only lout the primary beam and not the primery plus scattered bean which is ectudily prodacing the exposure. In addition, the process of obtalning an absorption curre presents many pitfalls to anyone but the experienced radiologist and physteist. This was olearly demonstrated to the writor in revieuring some selected past results at Eochester Where special studies wore made to obtain low intensities and as monochromatio a bean as possible with high amounts of filter (results not published). In attenpting to obtain the half-ralue-layer under these high anounts of filtration, the results showed high rulues; and the recent estitiation of the effective energy from the former results ghowed that the effeotive energs would oalculate to be muoh higher than the poak voltage of the $x$-ray mechine. This tas obviously not possible. The resson for this error wo that $*$ considerable portion of the exposure recorded by the lonization chambers was produced by photons whtoh hed been scattored around the pilters. These errors mere not detected since an effort was made only to obtain the "halfralue-1ajer" and the effective energy ras not caloulated. ThIs also enphasizes 
DTCLASSIFIED

the fact thet the halforalue-leyer can, in some cases, be very unreliable sna that in many eases the half-value-layer hay have no real signifionge to the person making the study.

Wethod. The systen of quality ereluation under consideration by the writer is that of determining the retios of readings from Ionization ohembers containing inmer lintngs of warious thaterials. Dufing the early days of quantity measurement of x-ray beam output muah effort was expended in detersining the criteria for fabriogting energy independent lonization ohavabers. In fact, the standardized use of ionization chambers in quantity measuzenent of $x-x$ ays was delajed for nexply tro docades due to the engrgy dependence of the various ehmbers used in addition to the poor quality of accessory voltegemeasuriog devices. The proposed method of quality eraluation makes use of the onergy dependence of chambers which incorporate netal Iiners of arerage atomic nunber gregter than 11 .

The first gtadies were made using $x$-ray machines operated in the range

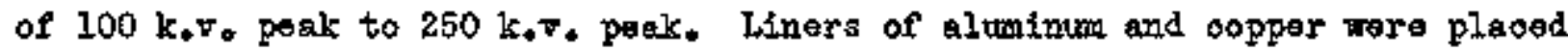
in some $0,25 \mathrm{r}$ condenser I mater chambers purohased from the Victorean Instrunent Company. In the cese of aluminum liners the notal thiokneas of $1 \mathrm{mil}, 2 \mathrm{mil}$, and $5 \mathrm{mil}$ mere used and the liners were construoted so that they would fit snugly against the inner walls of the condeneer $r$ meter chambers, In the case of copper liners the thicknesses uked were 1.5 mil, 2.5 mil, and 4.5 mil. Comparison of the readings of the chanbers with the aluminum liners to the readings from condenger $r$ neter chambers which hed no ifners and could be considered as "air-mall", showed thet as filter was added in the port below the $x-r a y$ tube the ratio first increased when the thinnest filter mas placed in the port and then the ratio decreased gradually. It had been expected that 
the ratio would deorease continually from no filter to heavy filtration sinco the ratio of absorption of z-rays by aluninum to that of oarbon, nitrogen, and oxygen (oharacterigtic of tisgue and atr absorption) would deorease with inoreasing effeotive energy of the $x$-ray beans. The first inorease in ratio from no filter to light filtration ras considered to be due to the fact that, under conditions of no filter extermal to the tube, the effoctipo energy of the x-ray bean was very low, Since the chambers were approrimately $1 \frac{1}{2}$ inches in diameter and the range of the electrons released fron the chamber walls was less than the ohamber dierseter, we did not have total wall effect in the chambers. In order to heve the system work properly the wall effect must be greater than 90 per cent of the affect producing the lonization in the chambers.

For this reason pocket pergonnel ohambers which were purohased from the Tictoreen Instrument Compeny were resined out such that nothl liners could be inserted into the ohambers. The liners were mede suoh that the inaide dianeter of the liners were equal to the original inside digmeter of the pocket ohambers. With these chambers it mas found thet the greater share of the ionization produced within the chambers wes produced by the electrons released from the walle in the range of $x-r a y$ peak rolteges from $100 \mathrm{k}$. $\mathrm{v}_{\text {. to }} 250 \mathrm{k}, \mathrm{v}$. and filter thicknesses greater than 0.25 men of copper. Fren at low filtration most of the ionization in the chamber was produced by electrons released frcm the ralls. Therefore, ionization chembers with inside dianeters less than one centimeter oould bo used in this type of quality evaluation in the r-ray peak energy range of 100 to $250 \mathrm{k}$.

In studying the results of the ratio of aluminum-lined chambers to "afr-pral1" chembers it was noted that the ratio increased with docrease in the effective energy of the x-ray beem, at was expected theoretically. The purpose JRELASSIFIED 


\section{DECLASSIFTED}

of using the metal liners in the chambers was that theoretically the number of eleatrons released from the almanm Iining would bo proportional to the x-ray onergy absorbed and this in turn would bear a relation to the erfoctive mass aborption cosficient profided that the liner thicknessed were approrifately equal to the range of the most energetio electrons released from the altuinum. In addition the elactrons releaged into the "air-wall" ohamer would bear relation to the effective mass absorption odeffioient for air. In the range of 100 to $250 \mathrm{k} . \mathrm{v}_{0}$ peak the optistan thickness of aluminum liner was found to be 2 mil with the 1 mil and the 5 mil liners each giving 5 to 10 per cent less fonfzation within the ohamber.

At present the method of quality oraluation, which is being utslized in studying filter and soatter oonditions under park $x-2$ ry energies of 100 to 250 k.T., oonsists of deteraining the ratio of readings fram a 2 intl alominumlined chamber to an "afr-rall" ehamber and using the ratio only ar on indiention of the effective energy. Further studies are oontinuing in an attempt to assign an effeotive energy to the ratio of the chamer readings. Experfments to date have aleo indicated that in the range of 100 to 250 k. v. peak, copper linere should not be used sinee the copper gires excessive weight to lor energy photoms and also the ratio of copper to "alr-wall" ohamberg becomes so high under certain oonditione that the ratio oannot be determfned rery accurately whth one sinultaneous exposure. Studies hare also indicated that the ayoten is not very useful in the range below $100 \mathrm{k}, \mathrm{v}$. peak tue to the short range of the eleotrons released from the walls, However, for therapentlo uees most $x-r a y$ machines will be operated wall above $100 \mathrm{k}$. F. peak and some filter is also used with the rachine. In quatity evalugtion arowd the $100 \mathrm{Kor}$. penk x-ray machine retios of copper-lined to "air-walled" ohamers wero ueed at 


\section{TRCLASSIFIED}

first and recently the retso of tin-lined to copper-lined ohambers hare lad been used to erold the exaessive ratght the copper or tin linere give to the Ior energy phatong relative to the weight given by "air-wall" chembers.

Results. The primary epplication for the system was found to be tn the quality eraluation of the $1000 \mathrm{k}$.T. peak $x$-ray machine. There the problen of reducing the radiation around the filiters in making an absorptiọn stady is multiplied several fold since the mergy of the radistion is so higho In the studies an absorption curve was first ande with the filter noar the end of the x-ray tube. However, it was mounted approximately 4 inohes below the one foot thick conorete oeiling which surrouaded the $x$-ray tube. As ahom on ourve A of Plgure 1 (Page go), a straight line portion could not be obtainad on a semi-log plot of the absorption ourve oren up to litinohes of lead. Sinultaneous with the gathering of date for the absorption ourve, the ratio of readings of a opper-ifned chamber to an "air-mall" chamber was obtalned and the resulte are shown in curve $A$ of Plgure 2 (Page 80),

As previously stated, the lower the ratlog of readinge of the copporwall to "air-welln" chambers, the higher it the offeotive energy produoing the exposure on the chambers, As shom by curve A of Figure 2 , the firat $\frac{1}{6}$ inob of lead filter made the bean slightly higher in effeotive enorgy. Howerer, further additions of load filter made the effestive enargy much lower. This Indicated that curve A of Pigure 1 was not a reliable ebsorption ourve sinco considerable scatter the ooming around the side of the filterg. An attempt was then made to reduoe the sostter around the filter and this was flrst done by moving the filter close to the $x$-ray tube stach that the bottom lead filter was flush with the bottom of the conorete ceiling. Curres B of Figures 1 ud 2 resulted. Following this a one foot wide, 光 inch thick strip of load wa. 
Figac z. - Ratio of coppor-14ned chuber readinge to graphl to-linod chamber readinge

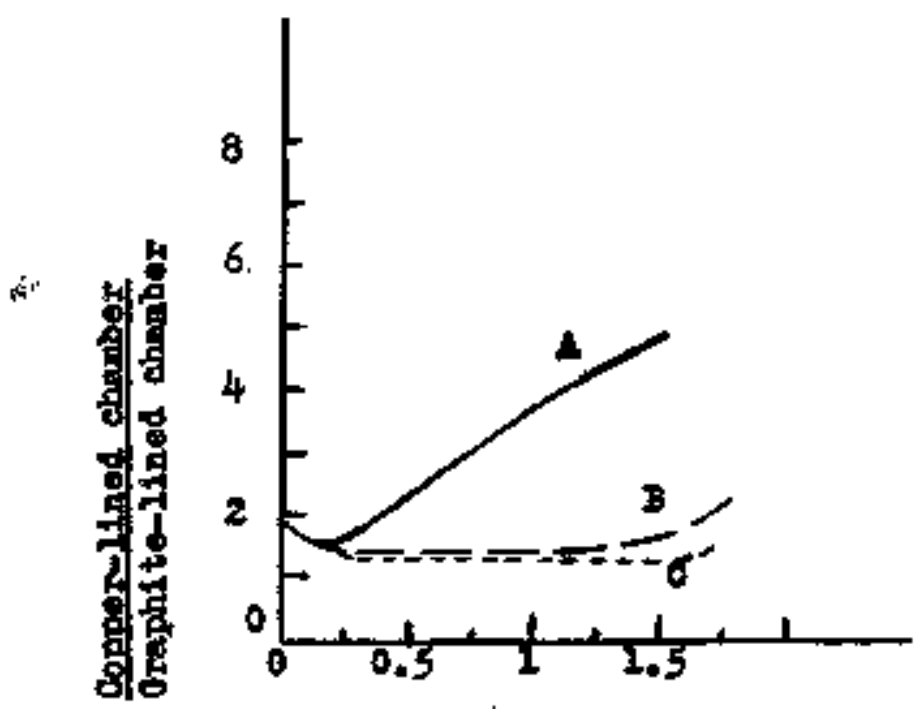

Thicheres of lead filter in Inches 


\section{DICLASSI FIFD}

mounted on the conorete ceiling around the port opening inte the exposure roon. Belor this a $\frac{1}{2}$ inch thick sheet of lead was mounted orer the port with a 6 Inch diameter centered hole thereby acting as a diaphragm for the z-ray beam entering the exposure room. The absorption curve was then determined with the filtera mounted above the diaphragm and ourves 0 of Fugures 1 and 2 (Page 80) were obtasned.

In another application a $z$ tudy was nade of the effective onergy rarlation between locations near the diaphragm motuted on the cefling end the various positions between the deiling and the concrete floor of the exposure rocm (the exposur' room beigg epproximately 9 feet high). The ratios of tin-lined chambers to copper-1ined chanbers raried fron 1.2 near the diaphragm to 1.6 on the floor. There mas a continuous incrase in these ratios as the chambers were nowed from the oeiling to the floor of the exposure room. Thts Indicated that the floor was produoing a great deal of scatter. Four feet by four foet pieces of lead of partoug thicknessea were pleced direotly beneath the matal chambers which Fere rounted one foot above the floors and it was found that $2 / 8$ boh of load reduced the ratio from 1.64 to 1.34 . Further thicknossos of ledd on the floor would not decrease this ratio thus indiouting that lead of 1/16 inch maximatum thiokness rould be very helpful in reducing the acatter from the floor and making the exposuring beam the hardeat posalble for any one condition*

Conclusions. The above sesults demonetrate that using the ratio of readings from chambers having different metal liners oan bo of grent asoistance in assuring that the maximual effective energy of an exposing $x-r$ ay beam is obteined. The ratios al me cen be used as a messurg of the hardnest of the exposing beam afmilar to the use of the helf-value-layer. It is folt that 
through further studief the ratio of ohamber readings can be correlated with a "biological effeotive energy". A preliminary report will be released in the neer future iving more detalis of the theory of the system.

Problem codes I. M, I (Research and Developinent)

Seotion codes 3110

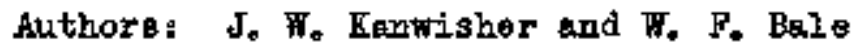

Iomizing Eadiation Dosimeter.

Background, This report indicates the feacibility of a new type of high range ionizing radiation dostmeter, oomaonly knom as a cesualty dosimeter, This dosineter is based upon the inorease in oonduotfitty in the water Jayer of a water-oarbon tetrachloride or water-ohloroforn system gealod in a foumtain-pen-rized, 11 pht-opeque, pyrex-glass-lined capoule, Bosage is read by a portable eleotronic dertoe besed upon the q-sater in prinoiple, increasIng conductivity following 1,rradiation produces correspondingly groater electrical losies in the meter circult. Thess losses are read on a dial calibrated in $r$ tuitis.

This instrument is frankiy based upos the oolorimetrio dosimeter developed by Taplin and Douglas $(1,2)$. Taplin and Donglas hato developed, in a preliminary forti, a dosineter based apan the reported linear relationship between the acid evolved from ohloroform and the anergy absorbed by it. $A$ two phase systens measures the acid produced colorimetricelly. After radiation, the aoid 1. iberated diffuses into the aqueous phase, reducing the $\mathrm{pH}$ and ohanging the ofor of the dye (brom oresol purple). Compared with its Taplin and Douglas prototype it hes several probable advantages and at least one potential 
disedrantage。

1. In the Taplin and Douglas instmument the color change ocours chiefly at one value of dogege. Thus s separete chamber mut be included for edoh dosage that it is degirable to measure. In contragt one liquid chamber in our finstrument is sufficient to measure any radiation dose from 50 to $1,000 \mathrm{x}$.

2. Our instrunent has the light excluded oven during dosage rosding. It contains only two oomponents, peter plus chloroform or carbon tetraohloride. In oontrast the prototype Taplin-Douglas instrument oonteins in addition a pH sensitive dye and rast be obserred vi bually for roading purposes. It has not yet been conclusively proven that this dosimeter is stable for perlods of months or years under these eonditions. The simple two phase system with light excluded has potentially s longer pertod of usefulness.

3. Our instrument reported here needg an auxillary electronic instrunent for reading purposes, not required wh the visudily read Taplin-Douglas instrumant. Such a reader, it is belleved, oan be developed that will not be expensive to constmuct, Ilght weight, and easy and repid to use, possessing the adventage of giving exposure directly on a ealibrated meter. Fith one meter many dostimeters can be read, probably as fapidly as 5 seconds per individuel dosimeter.

Wethod. This rork was based upon the Idea that the developmontal progran of Taplin and Douglas on a dosimetric dosimeter wight be usefully eupplezpented if a reader could be produced independent of visual observation and whout the incorporation of a dyo. It mas folt that these tro footors might linft the gtability and ecorracy of the Taplin and Douglas instrument. Our initial idee was that $\mathrm{pH}$ or conduotivity might be read by electrodes permenently sealed into a glass capsule containing the two liquids, Both of 
the se effects are of a magnitude subject to eagy magsurement. For example, our measurements in preIiminary experiments showed a change in pH of the water layer from 6.05 to 3.4 when approxjately one to one ratios of water and ahlorofom were Irradiated with $500 \mathrm{r}$ of $x-r$ ays fran a 200 peak k. $v$, generetor. Similar experinente with $\mathrm{C} \mathrm{Cl}_{4}$ - water filled tubes geve pH ohanges of 6.1 to 4.0 following $500 \mathrm{r}$, Such order of magnitude resulits are oogesstent with date reported by Teplin and Douglas.

Heasurenents of conductiofty in water following the irradiation with a $450 \mathrm{r}$ dose of equal volume salutures of $\mathrm{CHCl}_{3}$ and water bhow changes in conductivity of Iron 30,000 ohms for non-irradiated controls to 400 okms following irradiation.

As a means of reading electriosl conductivity of prototype dosineter tubes with built-in electroded, light portable battery-powared AC bridge wa conetructed. A 1,000 cyole osclilator utilized is tube. Detection of bridge unbslence was made with earphones, Ho amplifiostion was nocessary. This reader, aconplete wfth batteries, weights about one pound.

The problem of a design of dosimeter with built-in conduotirity electrodes, cheap and easy to menufacture, has, howerer, not been solved. Tha apparent necessity of using platinur electrodes, fabrioated with fair precision and senled in pyrex glase, suggested that this dosimeter may be somemhat more expensive to produce then is destrable.

When proliminary experinents indloated that by otilizing radio-frequenotes in the neighborhood of 10 megaoycles, the use of internal electrodes might be entirely elininated, work was extended in this direction. Studie日 on Radiofrequenoy Detection of Condictivity. Ta achieve maximm usefulness an individisal casuality-type dosimeter ought to be ohap. 
manufacturing oost under a dollar and preferably not more than a fen conts, ansily manufaotured, rugged and with a long "shelf" Iffe Providing a satiefactory "reading" apparatus oan be developed, a dosimeter in which conduotivity is read by radiofrequency meane without oleotrodes sealed into the liquid sompartment has distinct advantages. The dosimeter is reduced to the simple form of a small pyrex glase tube, probably onoased in a thin ouralope of opaque plastic to prevent exposure to visible and ultraviolet light and to add ruggedness to the dosimater.

To investigate the feasibility of radiofrequenoy oondiotivity menturementa a commercial type radiofrequenoy bridge was ut1lized with a atandard aignal generator and recetver equipped with an "S" meter. Typionl of aapoulea tested rere pyrex tubes 10 inohes long, 1 fnch in dianeter, $7 / 8$ flled with equal parts of oarbon tetrachlaride and water. A typioal frequenoy ued mas 6 megacyoles. The mater phese was plaoed inaico a ooil, 30 tarne and 4 inches long which made up the unknown arm of the bridge. Separate readings of $L$ and $R$ were obtained. The $L$ readings, in general, were oonstant for $\theta$ given ooil and gecanetry of doaimeter tabe. The $\mathrm{R}$ reading obteined depended upon the radiation dose that the dosineter has received. It esened obvioug that a reader of this type oould be developed seneftivo to a radiation dose of 25 I or less. It probebly would be entirely feagible to develop portable reading apparatus based upon this principle。

Study of a Q-15otar Type of Detector. It mas noticed that the I and $\mathrm{R}$ readinge on the bridge could be interpreted in terme of the $\mathrm{Q}$ of the coll in whioh the dogimeter is fnserted. Changes in oonduotivity gire rise to changes in $q$. The feastbility was, therefore, investigated of cometruoting a dostmeter reader besed upon the prinosples of the Q-meter such ax Boontom 
model. In prinotple such a reader oonsists of a radiofrequenoy osoilletor feeding a signal into a coil into which the dosingter tube fite. Tith the dosineter in the ooil and the coil circuit tuned to resonance, the vol tege developed across the ooil is the original fed roltage multiplied by Q. This final voltage is read by a high impedanoe vaound tube vol trineter. Inoreases in dosimeter fluid conductivity would be indioated as deorease fn this output voltege read by the vaourur tube roltmeter.

A dosineter reader beed upon this prinoiple hes been developed and found to have adequate sensitivity for the desired purpose. Flgure 1 (Fage 87) gives sohematioelly the ofroutt now in use. Figure 2 (Page BB) shows the first portable model constructed. The oscillator is a feedback type employing a 1s4 tube. Coupling to a Ior impedanco load is eccomplished by a angle turn on the coll form. The oscillator frequency is 10 megacycles.

The cot1 in which the dosinetar tube is Inserted is 11 inches long and wound on a $1 / 32$ 1nch wall polystyrene form with a inoh center hole. Finding 1s 22 gauge enameled wire. Dokineter tubes now in use are fabriceted fram atandard 10 millimeter pyrex tube. They are $4 \frac{1}{2}$ inches long, filled $7 / 8$ full with equal parts osrbon tetrachloride and water or chloroform and water. The tube is inserted until the water phase, which floets on the chloroform or oarbon tetrachloride, ocoupies the space within the coil.

A standard electroneter type of circuit was adapted for use as the vecuun tube voltineter. This provides the necessary high tmpedance input to prevent loeding dom the coil. The tube is biesed well belor out-off. Changes in the electranster tube bias dath be ueed to vary the aensitivity of the weter in terss of indicated radiation. Gonduotivity ohanges protuoed by radiation doses of $50 \mathrm{r}$ cen be sasily measured with this unit. 


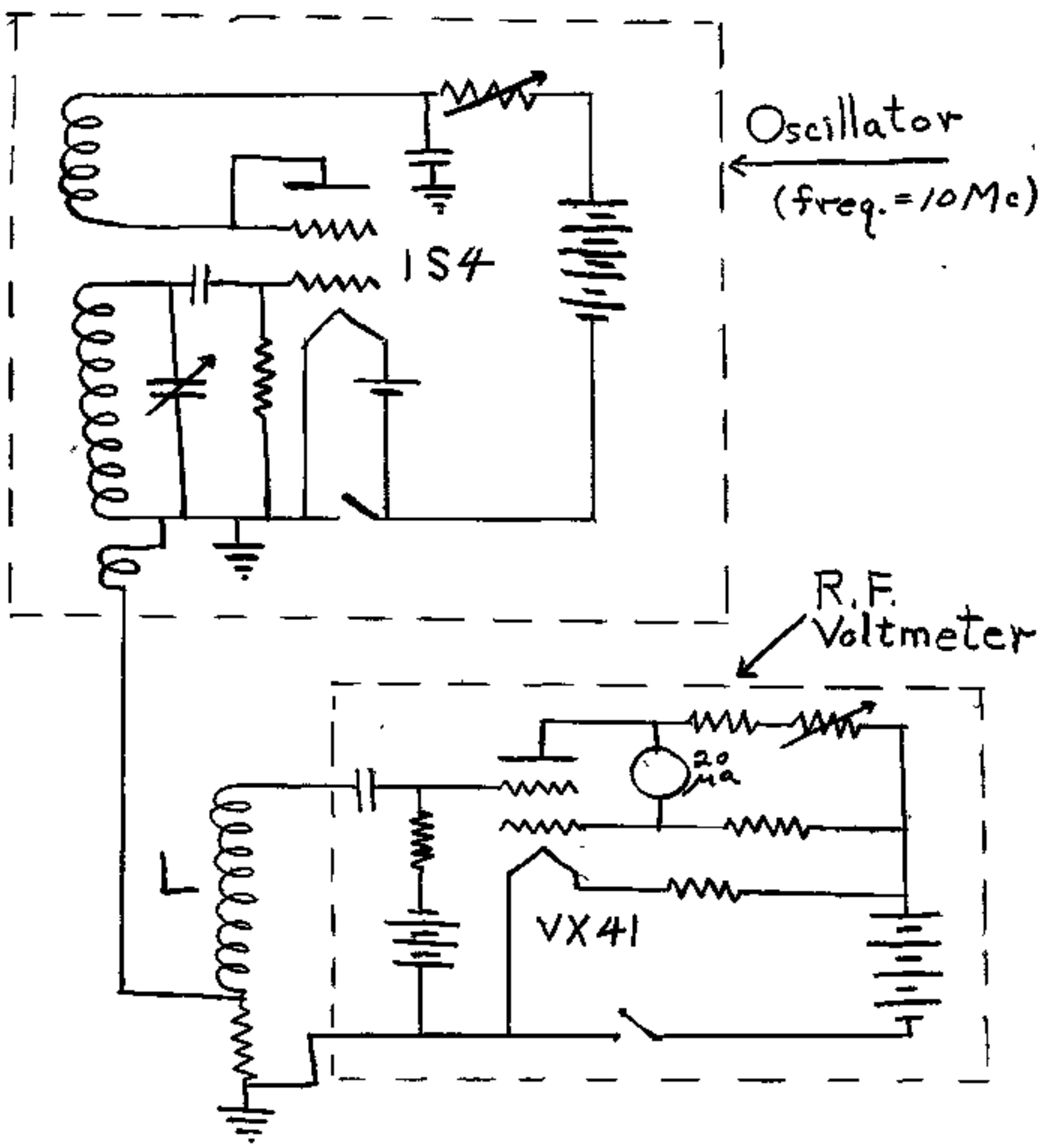

Higare 1

Q Hoter Curcutt. the change in " $q$ " of the coil I is interpreted in terms of dose recolvef by the capsute incorted in $\mathbf{l}$. 


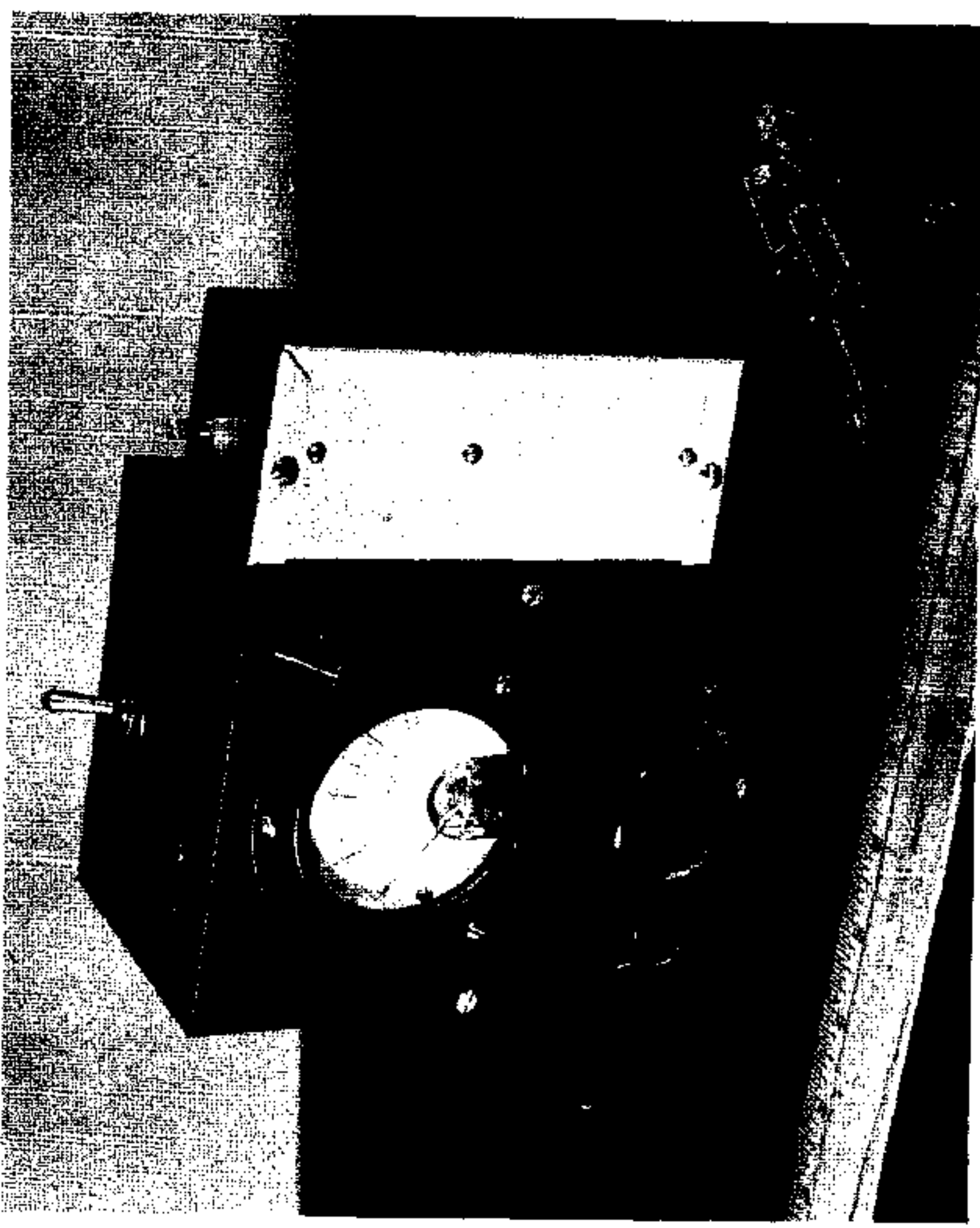

$\leq$

$\theta$ 
89.

\section{OHCLASSI FIED}

It appears feasible to design s small, Iugped, light wofght, and reietively inexpensive dosineter reader based upon this prinoiple, The unt illugtrated in Fgure 2 (Page 88 ) is $4 \times 3 \times 5$ inohes and we1ghs under three pounds. It 1s the firat experimental unit oonstructad and no grept offort has been expended to ingrense sensitivity and portability.

\section{Bibliography}

1. Taplin, George $\nabla_{0}$ and Douglaa, Clayton $H_{4}$, UCLA-58, December 29, 1949

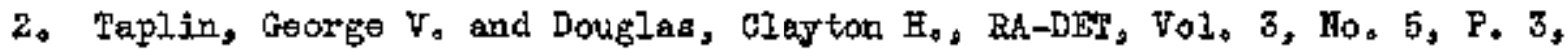
Hay 1950

Problem Coder I. Ho2 (Service)

Section code: 3150

Author: L, To Steadman

1. 73 chsmber afr semples were analyzed for zirconium

2. 4 air dust sagples more andyzed for beryllitm

3. '2l2 animal tisnes were anglyzed for beryllim

4. 4 antmel food samples were analyzed for beryllium

5. 15 human autopsy samples wore anglyzed for uraniun and beryllium

6. 25 chanber air anmpleg wore analyzed for thoriun

7. 7 miscolleneous samples wore cuslyeed for constituent elements 
EDUTCATIOEAJ, PROGRAL

\author{
Problem Codes None \\ Section Code: $\mathbf{3 4 8 0}$ \\ Author: J. $\mathrm{H}_{\text {o Stannard }}$
}

Balaiolog leal Physics Gourse. Daring this quarter the finel phases of the academic progres wore oxmplated. A sourse ntitlod Praotionl Radiologital

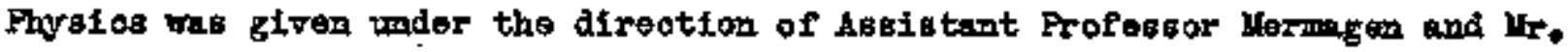
Hoyt Thipple。 An outline of lectures and laboratory exerelses follor (Pages 9l. 92). It will be noted that this course takes up in order the sore urgent practical health problens resulting from the proparation and ase of fibaionablo matertsls in the release of nuelear energy. In addition, some instruotion in neoting hospltal torey and radim problems is included.

The pratical treinfig for five of the group is belng ocatinued at Brookhaven Fatlonal Laboratory this alnmer under the auspioes of thair Heal th Physics DHvision. Oring to lack of housing at Brookharea, those stadents with fenilies are regaining in Roohester this gumer to pursue researoh problems.

All stadents began preliminary researoh inveatigatlons daring the quazter. $\Delta$ list of these is attaohed (Page 93),

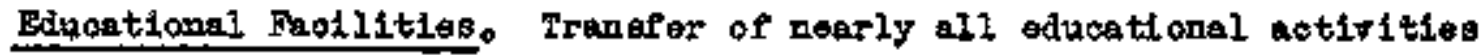
to new addition to the Nedias Sahool building was oomploted durfing this quarter. Bquipment requiremeats for each course vere deteroined in dotail by the responsible instructors and the task of fitting up laboratortes for an expended student body is under ray. 
PRACTICAL RADIOLOGICAL PHYSICS

LECLIURE SCELDULE

Honday and Fiday - 10:30 A, $\mathrm{K}_{0,}$ Tuesday end Thuraday - 9:00 A, $\mathrm{H}_{0}$

Lay 1 to June 9,1950

Topis

Lectares

1. Introduation and Hiatory

Mermagen

2. Heximann Permidaible Exposure

Herrogen

3. Unite

Whipple

4. Bragg-Gray Prinoiple

Thipple

5. Frinciplea of Yeasurement

Mermagon

6. Factors in Dasign and Use of Instriments

Thipple

7. Survey Instruments

Dabl

8. Surrey Yethods

Pintpple

9. Radioaotive Leboratary Desiga

Andrems

10. Exaretory ligthods for Bto-disay

Stanniurd

11. Hematological Blo-Assay Lethod:

Ingran.

Ditoustion

Staff

Quiz

12. Taste Disposal

Bale

13. X-rey Ingtallation Safeguards

Merimegran

14. Plant Hesl th Fhyles Wothods

Hermagen

15. Correction of Substandard Conditions

Finipgle

16. Shlelding

Thisplo

17. Atconic Disaster

Horland

18. Seminar' Expertment Bummaries

Students

DNCLASSI BI WD 
Topfo

Lectirey

Sumary, Review and Discusesion

Stafe

Examination

\section{IABORATORY SCHEDULE}

Tresday and Thursday $=1,00-5,00$ P.M.

1. Thotographio Dosinotry

2. Photographic Dosimetry

3. Instrument Calibration

4. Beta Activity Analyaia

5. Decontamination

6. Practical Iaboratory Survey

7. Gelotron Heutron Measurementa

8. I-ray Calibration of Low and Hogh Voltage Genaratora

9. X-ray shisldingt 


\section{A. Z, C RADEOLOGICAV PHYBICS MULONS}

RISEARCEI ASSIGRGENTS

Fobruaty 24 through June 9, 1960

Student

Geo. Mo Ansleton

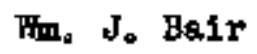

Robt. F, Barker

Sturgt C. Elsck

John C. Callimore

Paul Do Shandley

Geo. Ao Simon

Lamrence Thomas

Theodore Tretensibe

Donald Morken
Probletwin

Instruator

Stencminat

tion of fission producte

Protein synthesle with radionotive anifno acids

Krtenston and anplificktion of eurrent tolerance aslculations for internal enditters

Depth dose detarminations

Aggregater and radio-colloids as factors affecting diatuibution of radioactive materials in the body (Axtoradiographio attack)

Radiumoradon deteminations

Spectroohemical methods for dateralnation of flsaton produota (different substances then used by Angleton)

Asgregates and radiomcolloids as factors affecting distribution of radioactive materials in the body (oorrelative physical measurementa)

Inleotromaticroscopy of goft tistus with particular reference to the respiratory systom

Datolopment of an anglytion fluoraphotameter for the study of profect metaly
Hursh

Steadersar

Stamard-Boyd

Laskin

Fouman 


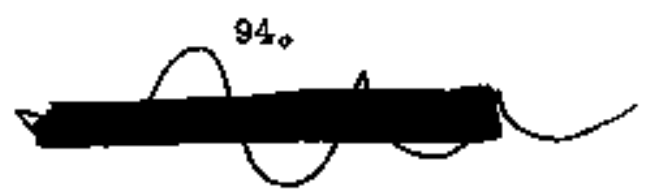

TECHHICAL REPORTS ISSUED FOR DISTRTBUTION

Glassffied For official Usa only or Lower

Apr\$1 1, 1950 thru June 30, 1950

\begin{tabular}{|c|c|c|c|}
\hline Report Non $_{0}$ & Ititlo & Authors & $\begin{array}{l}\text { Sabject } \\
\text { Category }\end{array}$ \\
\hline JR-103 & 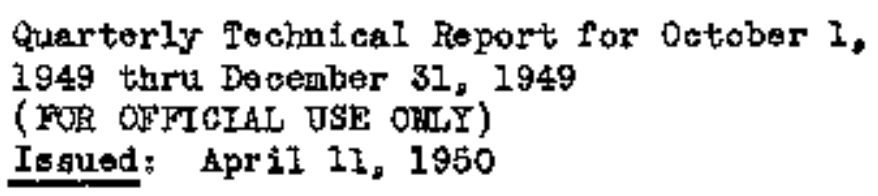 & Blair & $\begin{array}{l}\text { Hoalth } \\
\text { end } \\
\text { Biology }\end{array}$ \\
\hline JR-108 & 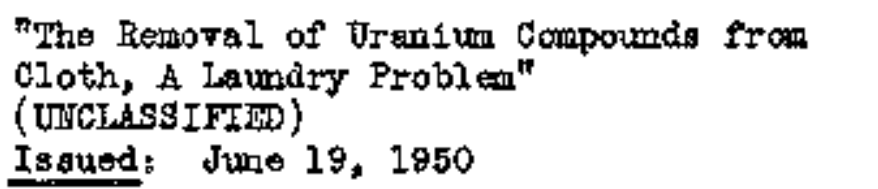 & $\begin{array}{l}\text { Carlson } \\
\text { Feuman }\end{array}$ & $\begin{array}{l}\text { Fealth } \\
\text { and } \\
\text { Biology }\end{array}$ \\
\hline UR-109 & 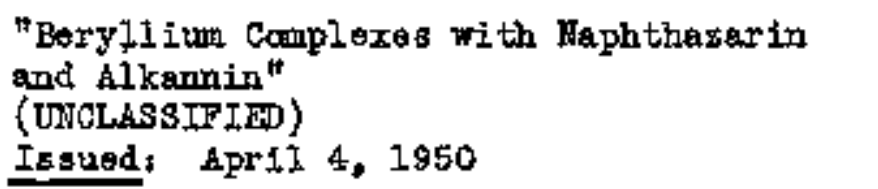 & $\begin{array}{l}\text { Undermood } \\
\text { Toribart } \\
\text { Yeuman }\end{array}$ & $\begin{array}{l}\text { Ghentistry } \\
\text { General }\end{array}$ \\
\hline $\mathrm{JR}-110$ & 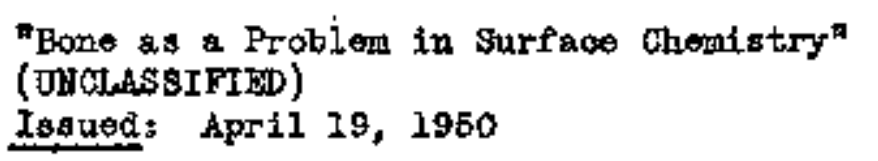 & Neimen & $\begin{array}{l}\text { Heak th } \\
\text { and } \\
\text { Btology }\end{array}$ \\
\hline UR-11. & 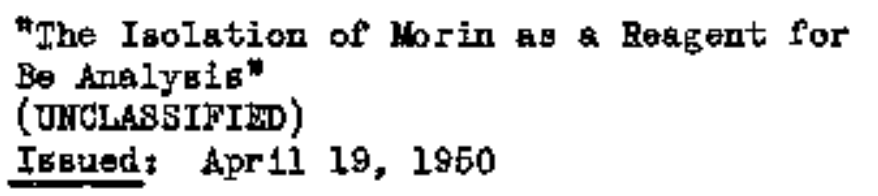 & Bonnar & $\begin{array}{l}\text { Chemistry } \\
\text { Genertil }\end{array}$ \\
\hline $\mathrm{VR}-118$ & 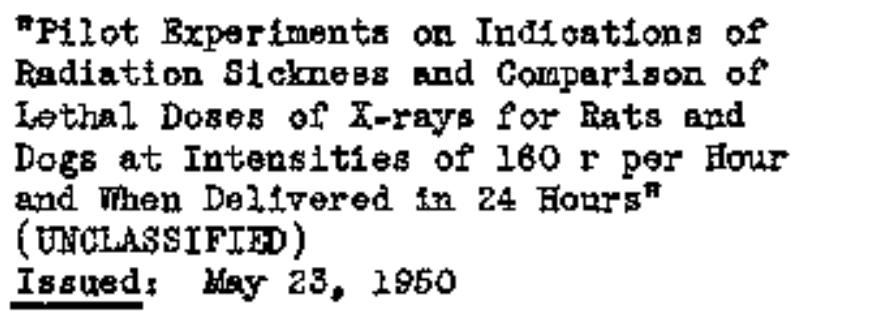 & Casarett & $\begin{array}{l}\text { Health } \\
\text { and } \\
\text { Biology }\end{array}$ \\
\hline IR-114 & $\begin{array}{l}\text { "The Surface Chemistry of Bone } I_{0} \\
\text { Fluoride Deposition" } \\
\text { (TNCLASSIFIBD) } \\
\text { Issued: June } 1,1950\end{array}$ & $\begin{array}{l}\text { Nermen } \\
0 t \text { a }\end{array}$ & $\begin{array}{l}\text { Foelth } \\
\text { and } \\
\text { Biology }\end{array}$ \\
\hline JR-1.15 & 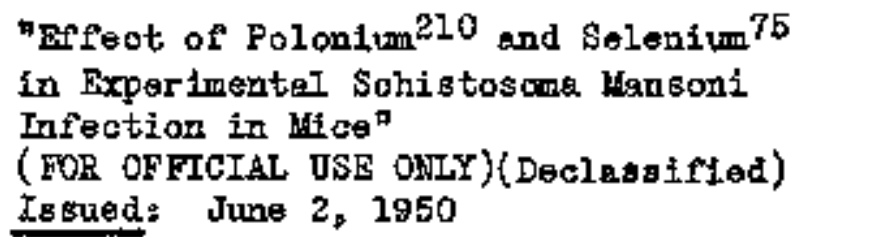 & $\begin{array}{l}\text { Fatts } \\
\text { YoConnell }\end{array}$ & $\begin{array}{c}\text { Health } \\
\text { Band } \\
\text { Blology }\end{array}$ \\
\hline
\end{tabular}


Beport Nog

UR-116

UR-119

UR-120
Titelo

Quarterly Teohnioxl Report for Januery 1. 1950 thru Karch 31,1950

(FOR OFFICIAL USE OHLY)

Igsued: June 29, 1950

JR-117 $\pi_{A}$ Kinetis Study of Hormal and

Uranium Inhibited Hexose Letabolism

in Yeast"

(FOR OFITCIAJ USE ORLY)(Deolasaified)

tesued: June 2, 2950

"The Radiun Content of the Body for Indifiduals whth no Bnom Dcouptional Exposures" (UNCTASSIFIED)

Isaued Jime 30 , 2960

"The Belationship of the Cell Surfece to Hetal. VII. The Chemianl Hature of Uranitu-Conplexing Groupe to the Coll surfacen

(CONFDHNTAJ) (Deolasstetied)

Isaued: June 23, 1960
Subject

Authore

Gategory

Bletr

Heal th

and Biology

Hurwtz

Eealth

and

Eiology

Firsh

Hoalth

and

Biolog

Rothetoin

ot al

Fealth

and

Biology 